\begin{tabular}{|c|l|}
\hline Title & $\begin{array}{l}\text { Environmental hormesis, a fundamental non-monotonic biological phenomenon with implications in ecotoxicology and } \\
\text { environmental safety }\end{array}$ \\
\hline Author(s) & Agathokleous, Evgenios \\
\hline Citation & $\begin{array}{l}\text { Ecotoxicology and environmental safety, 148, 1042-1053 } \\
\text { https://doi.org/10.1016/.ecoenv.2017.12.003 }\end{array}$ \\
\hline Issue Date & 2018-02 \\
\hline Doc URL & http://hdl.handle.net/2115/76659 \\
\hline Rights & $\begin{array}{l}\text { ○ 2017 Elsevier Inc., This manuscript version is made available under the CC-BY-NC-ND 4.0 license } \\
\text { http://creativecommons.org/icenses/by-nc-nd/4.0/ }\end{array}$ \\
\hline Rights(URL) & http://creativecommons.org/icenses/by-nc-nd/4.0/ \\
\hline Type & article (author version) \\
\hline File Information & Manuscript.pdf \\
\hline
\end{tabular}

Instructions for use 


\title{
Environmental hormesis, a fundamental non-monotonic biological phenomenon with implications in ecotoxicology and environmental safety
}

\author{
Evgenios Agathokleous \\ Primary institution: Hokkaido Research Center, Forestry and Forest Products Research Institute (FFPRI), Forest Research and \\ Management Organization, 7 Hitsujigaoka, Sapporo, Hokkaido, 062-8516, Japan, evgenios@ffpri.affrc.go.jp, \\ evgenios@affrc.go.jp \\ Secondary institution: Research Faculty of Agriculture, School of Agriculture, Hokkaido University, Kita 9 Nishi 9, Sapporo, \\ Hokkaido, 060-8589, Japan, evgenios@for.agr.hokudai.ac.jp \\ correspondence: Tel: +81-11-851-4131, Fax: +81-11-851-4167, globalscience@ frontier.hokudai.ac.jp
}

\section{ABSTRACT}

The biological response of individual organisms or groups of organisms to stress is crucial in several scientific disciplines, and hormesis is the most appropriate concept for studying doseresponse relationships. The concept of hormesis supports that the response to low-level doses of an agent opposes the response to high-level doses and is characterized by a $J$ or $U$ shape outstretched in the Euclidean space. Hormesis has been widely known for chemical compounds and radiation; however, whether hormesis appears upon a variety of environmental factors remains underexplored. Here I provide evidence for the occurrence of environmental hormesis which opens Pandora's "pithos" for a wide variety of scientific disciplines. I demonstrate that plant response to environmental factors is often well described by hormetic model suggesting that dose responses should be evaluated based on a wide range of dose levels, taking into account potential effects at both low and high levels. I anticipate this study to serve as a starting point for more sophisticated experiments. The concept of environmental hormesis provides critical quantitative information for biological plasticity; is relevant to ecological and evolutionary theory; and may have long-term ecological implications within the context of global change. The concept of environmental hormesis can also be utilized for the benefit of human welfare and biosphere sustainability. However, to understand the underpinning biological or physiological mechanisms of environmental hormesis, trans-disciplinary research is needed. Environmental hormesis should be considered when developing science-based Environmental Quality Criteria (EQC).

Keywords: $\beta$-curve; biphasic; J-curve; plasticity; stimulation; U-curve 
34 The response of individual organisms or groups of organisms ${ }^{1}$ to stress is crucial in several scientific disciplines. Almost half a millennium has passed since the well-known 'all substances are poisons, there is none which is not a poison. The right dose differentiates a poison and a remedy' (Paracelsus, 1567). In order to properly answer which is the right dose, dose(or exposure)-response relationships should be investigated by exposing the organisms under study to different levels of exposure.

The threshold exposure-response model is the most commonly used model in toxicology/medicine (non-carcinogenic health hazards) which assumes that exposures to a toxin above a certain threshold level are dangerous, whereas exposures below the threshold level are safe (Calabrese, 2011, 2014, 2015). Later, the linear no-threshold model was used in medicine (carcinogens), which assumes biological injury directly proportional to the exposure. Both models utilize only high exposures for hazard assessment. Such linear models have been widely used in setting critical levels for protecting vegetation as well (e.g. Karlsson et al., 2004; Ferretti et al, 2007; Mills et al., 2007; Watanabe et al., 2010, 2012; Sanz et al., 2016; Marzuoli et al., 2017).

However, progress in science in the past two decades suggests that the fundamental nature of the dose response is hormetic and not linear or threshold (Calabrese and Baldwin, 2001, 2003a,b;

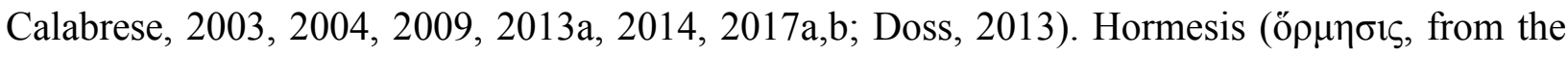

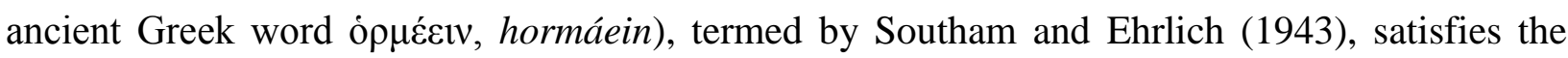
evaluation criteria and should serve as the default model in risk assessment of carcinogens and noncarcinogens for the purposes of regulatory agencies (Calabrese and Baldwin, 2003a,b; Calabrese, 2004, 2005, 2015; Cook and Calabrese, 2006).

In this article, I aim to review scientific literature so as to examine the hypothesis that plants may display a hormetic response to a variety of environmental factors as a result of physiological or biological stress, and provide a general overview of hormetic responses of plants to different types of environmental factors.

\section{THE CONCEPT OF HORMESIS}

61 Hormesis, initially called Arndt-Schulz Law or Hueppe's Rule (Yerkes-Dodson Law in 62 experimental psychology), is an underlying concept in biology which was marginalized 63 throughout the 20th century, until recently when attracted popularity (Calabrese and Baldwin,

\footnotetext{
${ }^{1}$ hereafter referred as "organisms" unless specified otherwise
} 

Corporation) for the years 1900-2016 revealed that 2423 articles included one or more of the

66

67

68

69

keywords hormesis, hormetic, hormesis, hormitic, ormetic, ormisis, ormitic and ormesis (website accessed on 17th September, 2016). Unsurprisingly, 2195 of the articles (91\%) were published from 2000 onwards, while 1044 of the articles (43\%) were published within just the past five years (2011-2016).

Hormesis is characterized by a $\beta$-shaped (Stebbing, 1982; Calabrese, 1996) or $U$-shaped (or $J$ shaped) response curve with $a<0$ or $a>0$ (Fig. 1), depending on how it is defined and on the biological endpoint measured (Calabrese and Baldwin, 2001). This concept supports that the response of organisms to low-level exposures to a stressor opposes the response to high-level exposures, with stimulatory effects occurring in the region of Menaechmus conic sections in the Euclidean space (Fig. 1).

Hormesis occurs and is similar both in susceptible and resistant organisms, although some strains may not generate low-level stimulatory response (Calabrese and Baldwin, 2002), and indicates disruption in homeostasis (Calabrese and Baldwin, 2001; Calabrese and Mattson, 2011). Whether the response of organisms in disruption in homeostasis is overcompensated remains unclear (Elliott, 2011) and requires further studies examining temporal response in order to understand the response over time and the long-term impacts (Poschenrieder et al., 2013; Mushak, 2016). The ideal overcompensation in such a disruption is when resilience can be achieved through plastic responses (Fig. 1, to the left of the toxicity threshold (NOAEL)). Hence, time is an important factor in hormetic responses (Calabrese, 2001; Mushak, 2016). Hormetic exposure-responses may form gamma $(\gamma)$-shaped (fish-like) curves when assessed in plant physiological endpoints early and late in exposure (Fig. 1). This phenomenon of $\gamma$-shaped responses indicates a modest overcompensation to disruption in homeostasis and not a direct stimulatory effect. A $\gamma$-like shape of curves shows that, at low exposures, the organisms respond to homeostatic disruption through overcompensation (re-allocation of resources), effectively repair the temporary damage and finally re-establish homeostasis (resilience).

Chemical and radiation hormesis (historical foundations in Calabrese and Baldwin (2000a,b,c,d,e)) commonly occurs in plants, as it has been observed more than 3100 times and in more than 3000 endpoints, and has quantitative features similar to hormesis in animals, with usually a maximum stimulatory response $<200 \%$ of controls and a width $<10$-fold (rarely $>100$ fold) in dose range (Calabrese and Blain, 2005, 2009, 2011; Hadacek et al., 2011; Cedergreen et al., 2005, 2007; Belz et al., 2008; Belz and Piepho, 2013; Calabrese, 2013b, 2015; Poschenrieder et al., 2013; Abbas et al., 2017; Agathokleous, 2017). Yet, hormesis is generalized as to stressor, 
plant species and biological endpoints (Calabrese and Baldwin, 2002, Cedergreen et al., 2007; Calabrese, 2005; Calabrese and Blain, 2005, 2009, 2011).

\section{ENVIRONMENTAL HORMESIS}

\section{Plant stress induced by environmental factors}

Many scientific disciplines study how stress affects biological systems over a range of exposure levels and a wide variety of biological endpoints. In a world with changing environment, plants often undergo physiological or biological stress which can lead to negative consequences in their fitness and productivity (Nali et al., 2001; Fiscus et al., 2005; Feng et al., 2008a; Saitanis, 2008; Yamaguchi et al., 2011; De Marco et al., 2013; Matyssek et al., 2015; Agathokleous et al., 2016a). Such stress-induced effects on plants may have further implications to biosphere and human welfare by reducing the food supplies and their nutritional value (Emberson et al., 2001; Feng et al., 2008a, 2015; Oksanen et al., 2013; Myers et al., 2014) and altering trophic interactions, ecological processes and ecosystem dynamics (Lindroth et al., 2010; de Vries et al., 2014; Karabourniotis et al., 2014; Simpson et al., 2014; Agathokleous et al., 2015, 2016a; Kitao et al. 2016; Wang et al., 2016).

\section{Hormesis induced by environmental factors}

Although not always mentioned in the scripts, indications for overcompensation stimulation in plants induced by low-level exposure to environmental factors have been previously found in the scientific literature for a variety of species and endpoints (e.g. Leone and Brennan, 1975; Roberts, 1984; Darrall, 1989; Eamus et al., 1990; Yalpani et al., 1994; Pääkköönen et al., 1996; Ranieri et al., 2000; Gray et al., 2003; Hernández et al., 2004; Luo et al., 2009; Nikolova et al., 2010; Calatayud et al., 2011; Ye et al., 2011; Franzaring et al., 2013; Hoshika et al., 2013; Rozpadek et al., 2013, 2015; Carriero et al., 2016). These indications were mostly based on experiments with three or less exposure levels, in terms of experimental units. However, hormesis induced by environmental factors has not been validated in terms of Euclidean geometry (with regards to the terminological context), despite the existence of some reports on its occurrence (e.g. VázquezYbarra et al., 2015; Mashaheet et al., 2016; Sugai et al., 2018).

A review of the relevant literature revealed that hormesis occurs as a result of physiological or biological stress induced by environmental factors (Fig. 2-5); however, studies with appropriate experimental design and sufficient statistical power for testing hormesis are limited. The vast majority of studies dealing with effects of environmental factors on plants were conducted on high-level exposures (distress) and adverse effects and their background biological mechanisms 
130 (see also Manning, 2005). However, the low-level effects (eustress ${ }^{2}$ ) and the adaptive 131 mechanisms (or resilience, Fig. 1) remain elusive, in spite of suggestions from the late 1980s that stomatal responses are contrasting between low and high concentrations of air pollutants and that 133 plants may show adaptive mechanisms and recovery from damage (Darrall, 1989), which 134 altogether hint to hormesis (Calabrese, 2014).

135 I present here for the first time 52 examples of hormetic responses of plants to environmental 136 factors (Fig 2-5). These examples come from 16 taxa, of which some include more than 1 137 cultivars or genotypes, and one peatland mesocosm. Hormesis was induced by 7 environmental 138 factors in 24 unique endpoints. The maximum stimulatory response occurred within a factor of $139<2$ below the NOAEL. Forty-one out of 52 dose-response relationships displayed both LOAEL 140 and NOAEL. The average LOAEL:NOAEL ratio of these 41 relationships was <2. In 50 out of 14152 hormetic cases, the low-level stimulatory response was up to $161 \%$ (Table 1), while in the 142 remaining 2 cases the stimulatory responses were approximately two-fold greater than the 143 control response. This is in agreement with hundreds of cases of chemical and radiation hormesis 144 explored earlier in biological organisms (Calabrese, 2013b, 2015; Calabrese and Baldwin, 2001; 145 Calabrese and Blain, 2009, 2011; Cedergreen et al., 2007). Among 52 exposure-response 146 relationships which displayed hormesis with treatments above $105 \%$ of control, $22(42.3 \%)$ had a 147 stimulatory response of $<25 \%$ of control (Table 1), which is not far from the $36 \%$ reported by 148 Calabrese and Blain (2005). However, calculations based on the modeled curves show lower 149 stimulatory responses, in agreement with earlier suggestions (Cedergreen et al., 2007). Based on 1503166 dose responses in plants, the probability that the maximum stimulatory response being 110$151149 \%$ of control would be $P_{(110 \leq \mathrm{MAX}<150)}=0.59$, independently from the endpoint (Calabrese and 152 Blain, 2011). The present study, based on 52 dose responses of mainly physiological, growth and 153 production endpoints to environmental factors, preliminarily suggests that this probability is $154 P_{(110 \leq \mathrm{MAX}<150)}=0.79$, whereas the probability that the maximum stimulatory response would be 155 up to $161 \%$ of control is $P_{(105 \leq \mathrm{MAX}<161)}=0.96$ (Table 1). It remains to be seen whether these 156 probabilities will be re-affirmed by a larger sample size of dose response relationships, perhaps 157 from a wide variety of studies which may take place in the future, however this provides a first 158 approximation.

159 The examined studies (Figs 2-5) suggest that hormetic responses can be cultivar- or genotype160 specific and endpoint-specific (Kress and Skelly, 1982; Weigel et al., 1990; Yamaguchi et al., 161 2012; Agathokleous et al., 2017a; Sugai et al., 2018). These hint to the suggestion that hormesis

\footnotetext{
${ }^{2}$ with respect to the roots of "eu" in Greek language (i.e. "cú", meaning good or well), the term eustress should be used only when the stress induced by low levels of exposure is beneficial
} 
is case-specific. Nevertheless, it seems to be occurring widely in a similar way both in susceptible and resistant organisms, in agreement with suggestion by Calabrese and Baldwin (2002). It would also be reasonable to examine exposure-response relationship separately for each endpoint as hormetic response is not necessarily observed in all the endpoints (Fig. 2-5). This is particularly important when assessing dry matter or biomass, which is also used in risk assessment (U.S. EPA, 2014), as there are indications that hormetic responses may vary among shoot, root and total plant (Fig. 5), especially for stressors which are likely to cause an imbalance in root/shoot ratio (Agren and Franklin, 2003; Grantz et al., 2006; Agathokleous et al., 2016a).

\section{Environmental hormesis}

171 As explained above, it has been previously shown that hormesis can be induced by a plethora of chemical compounds. This study provides evidence showing that hormesis can also be induced by environmental factors, such as gaseous air pollutants. Therefore, I propose to call environmental hormesis the phenomenon where hormesis is caused by environmental factors which induce stress to biological organisms at low and high exposure levels. Therefore, with respect to the suggestions by Calabrese et al. (2007) on biological stress response terminology, I suggest using the phrase environmental conditioning hormesis to refer to the phenomenon where prior stress induced by low-level exposure to environmental factors reduces the toxicity that would be caused by a subsequent more massive environmental threat (Calabrese et al., 2007,

180 Calabrese, 2015, 2016b). A variety of environmental factors was found to induce conditioning hormesis in plants (e.g. Yalpani et al., 1994; Ruiz-Sánchez et al., 2000; Hong and Lee, 2001; Fornes et al., 2007; Navarro García et al., 2011; Rozpądek et al., 2013, 2015; Kleiber et al.,

183 2017; Li et al., 2017). The phrase environmental postconditioning hormesis can also be used to refer to the phenomenon where a low-level exposure reduces the toxicity induced by a prior high-level exposure to environmental factors (Calabrese et al., 2007; Ovize et al., 2010). The environment has a central role in hormesis from a different viewpoint too. At individual level, organisms may attain survival through acclimation or adjustment to harsh environment.

188 Environmental stress forces the stressed to shape acclimation, adjustment or evolution in a changing environment, in such a way that the shaping depends both on the stressor and the stressed (Bijlsma and Loeschcke, 2005). At species or populations level, groups of individuals evolve features (e.g. adaptation via natural selection) which help them survive or reproduce in harsh environments. Natural selection is the cause of alterations over several generations through which particular traits are developed, thereby helping in surviving at a set of environments. In 
195 (Bohnert et al., 1995; Bijlsma and Loeschcke, 2005; McDonnell and Hahs, 2015); therefore it

196 should be fair enough to call the phenomenon described above "environmental hormesis".

\section{Suggestions}

198 It is now realized that environmental hormesis widely occurs in insects, nematodes and other 199 animals (Cypser and Johnson, 2002; Luckey and Lawrence, 2006; Rattan, 2008; Bocci et al., 200 2009; López-Martínez and Hahn 2012, 2014; López-Martínez et al., 2014, 2016a,b; Kishimoto et 201 al., 2017; Kumsta and Hansen, 2017; Kumsta et al., 2017) as well as in plants.

202 Environmental hormesis is not upon a direct effect of the abiotic stressor, but upon an indirect 203 effect through stress-induced changes in plant endogenous agonists. Oxidation-reduction reaction chemistry may play a central role in hormesis (Hadacek et al., 2011). Air pollutants, such as $\mathrm{O}_{3}$, and other environmental factors such as drought, are known to induce changes in reactive oxygen species. Hormesis may become more pronounced by time or may be a transient event (Calabrese et al., 1999; Mushak, 2016) as in Fig. 1, and thus adequate selection of time points would be needed. There is, however, a long way to go to conclude whether the stimulatory effects of environmental hormesis are beneficial in the longer term. Plant dry matter production may be a more appropriate endpoint for deciding whether hormesis is beneficial in the long run and for risk assessment as it reflects the accumulated plant stress (Larcher, 2003) and is already used in the ecological risk assessment (U.S. EPA, 2014).

213 Further research is needed on low-exposure response to test the effects on plants of poor

214 robustness and in adult and mature trees with closed canopy (hormesis age-dependency).

215 Environmental hormesis (Fig. 2-5) has been mainly found in semi-open or closed experimental 216 facilities with controlled environment. A big challenge for the next decades would be to assess 217 hormesis in pristine or to use open experimental facilities, where plants grow in a natural environment with interacting biotic and abiotic factors. For example, plants of the same species showed hormetic response to $\mathrm{H}_{2} \mathrm{~S}$ in diffusive conductance to $\mathrm{CO}_{2}$ when $\mathrm{O}_{3}$ was theoretically zero but no hormetic response when $\mathrm{O}_{3}$ was elevated (Fig. 2d). This can be explained by the decreased conductance which often occurs under elevated $\mathrm{O}_{3}$ (Felzer et al., 2007; Feng et al., 2008a; Ainsworth et al., 2012).

By testing the concept of hormesis, currently-unknown physiological and biological knowledge can be obtained. However, hormetic response duration (progression of stress) should be further investigated along with investigations of molecular mechanisms in order to enlighten environmental hormesis. Trans-disciplinary research is needed to understand the underpinning biological or physiological mechanisms of hormesis and develop hormesis as a biological 
principle. Multi-omics approaches may play a key role in elucidating the biological mechanisms of hormesis (Horgan and Kenny, 2011; Aliferis and Jabaji, 2011; Watanabe et al., 2015).

\section{RELEVANCE TO HUMAN WELFARE \& BIOSPHERE SUSTAINABILITY}

231

232

233

234

235

236

237

238

239

240

241

242

243

244

245

246

247

248

249

250

251

252

253

254

255

256

257

258

259

\section{Hormesis in human nutrition and medicine}

Plant stress induced by low-level exposures to environmental factors requires urgent studies because it may be occurring nowadays and may lead to changes in qualitative and quantitative properties of such important compounds.

Studies on accumulation of antioxidants, secondary metabolites and other stress-induced compounds within the context of environmental hormesis would be valuable since they are major players in plant stress and important for human nutrition and medicine (Piironen et al., 2000; Kintzios, 2006; Hadacek et al., 2011; Döring et al., 2013; Karabourniotis et al., 2014; D’Angiolillo et al., 2015). In this framework, low-level exposures of plants to environmental factors can be utilized in an efficient way to accelerate the achievement of marketable quality in cultivated crops and enhance the production of antioxidant compounds or other important to human nutrition compounds (e.g. Yalpani et al., 1994; Ranieri et al., 2000; Munné-Bosch, 2005; Wang et al., 2008; Rozpądek et al., 2013, 2015). Experimental results relevant to this concept suggest that environmental hormesis can provide critical information which can also be used for enhancing plant defense to a subsequent threat (Yalpani et al., 1994; Rozpądek et al., 2013, 2015; Li et al., 2017), and thus sustain higher yields.

\section{Conditioning hormesis in post-harvest engineering}

Environmental hormesis can be utilized not only to accelerate the achieving of marketable quality in cultivated crops and enhance the production of important to humans compounds by plants, but also for post-harvest purposes. One use would be to increase the post-harvest fruit adaptation to environmental stresses along with fruit quality in terms of human nutrition. For example, it has been suggested that preheating of grape berries (Vitis vinifera L. cv. Cabernet Sauvignon) induced accumulation of stilbene synthase (EC 2.3.1.95) mRNA and synthesis of a new protein of stilbene synthase (Wang et al., 2008). Stilbene synthase may enhance the phytoalexin defense mechanism against fungal pathogens of plants, and is of importance to human nutrition and medicine (Darvill and Albersheim, 1984; Kuć, 1995; Hammerschmidt, 1999; Piironen et al., 2000; Grayer and Kokubun, 2001). Furthermore, exposure of chilled-stored 'Thompson' seedless grapes, 'Black Amber' plums, 'Mareta' tomatoes and 'Nules' clementines to $\mathrm{O}_{3}$ protected them against grey mould (Botrytis cinerea Pers.: Fr (teleomorph: Botryotinia 
260 fuckeliana) (Tzortzakis et al., 2007), a worldwide important fruit disease (Jacometti et al., 2009;

261 Li et al., 2012). The authors suggested that "ozone may constitute a desirable and effective 262 residue-free alternative to traditional postharvest fungicide practices" (Tzortzakis et al., 2007). In

263 a further experiment, tomato fruits (Lycopersicon esculentum Mill. cv. Mareta) were exposed to $2640.05 \mu \mathrm{mol} \mathrm{O} \mathrm{mol}^{-1}$ for up to six days and then wounded and/or inoculated with grey mould and 265 transferred to clean air in chilled storage for one or two weeks post-fumigation exposure: It was 266 found that $\mathrm{O}_{3}$ protected against grey mould with down-regulation of ethylene $\left(\mathrm{C}_{2} \mathrm{H}_{4}\right)^{-}$, jasmonate $267\left(\mathrm{C}_{13} \mathrm{H}_{20} \mathrm{O}_{3}\right)$ - and pathogenesis-related genes (Tzortzakis et al., 2011). Other studies suggest that 268 an optimum $\mathrm{O}_{3}$ exposure can be used to delay ripening of fruits by mediating ethylene 269 biosynthesis inhibition and cell wall dismantling regulation and to enhance the physicochemical 270 characteristics, antioxidative capacity, and quality of fruits after harvest (e.g. Ali et al., 2014; 271 Minas et al., 2014; Segade et al., 2017; explanations also in Rice, 2002 and Martínez -Romero et 272 al., 2007).

\section{Suggestions}

274 The concept of environmental hormesis can be utilized for the benefit of human nutrition and 275 health by preserving food supplies and controlling chemical compounds produced by plants, 276 thereby ensuring human welfare and biosphere sustainability. However, attention should be paid 277 to diseases, pests and pathogens that may become more injurious to plants (Braun and Flückiger, 278 1989; Paoletti et al., 2007; Mashaheet et al., 2015; Agathokleous et al., 2017c; Abu ElEla et al., 279 2018).

\section{RELEVANCE TO ECOLOGICAL AND EVOLUTIONARY THEORY}

\section{Hormesis beyond individual level}

282 A big effort has been put by the air pollution research community and plant scientists to 283 understand the effects of future environmental change scenaria; however, do hormetic effects 284 (Fig. 3-5) indicate that plants are already facing environmental stress? Although knowledge remains inadequate, evidence indicates that there are taxa showing hormetic response to pollutant levels that are common nowadays in Northern Hemisphere (Fig. 3-5). Taking into account species-specific responses at low-level exposures (Fig. 3-5), it can be postulated that changes in composition of communities may already be in process and this may act as a driving force in ecological succession. This postulation is supported by recent findings where $\mathrm{N}$ deposition (1-19 $\mathrm{kg} \mathrm{ha}^{-1} \mathrm{yr}^{-1}$ ) effect on herbaceous richness of more than 15000 forest, grassland, shrubland and woodland sites across the continental United States was assessed to test the 
vulnerability to $\mathrm{N}$ deposition (Simkin et al., 2016). The authors revealed a unimodal relationship

293 where richness increased at lower levels of exposure and decreased at higher level of exposure

294 (8.7 and $13.4 \mathrm{~kg} \mathrm{~N} \mathrm{ha}^{-1} \mathrm{yr}^{-1}$ for open- and closed-canopy vegetation) and exceedance of $\mathrm{N}$ 295 deposition critical loads for loss of plant species richness in $24 \%$ of the sites. One model/theory 296 that predicts the shape of relationship between productivity and richness is the Grime humped297 back model (HBM; Grime, 1973, 1979, 2001). This is a classical example of hormesis where few 298 plant species can tolerate at low levels of productivity, many species thrive at intermediate levels 299 of productivity, and thus species richness peaks, and few species with high competitive capacity 300 can dominate at high levels of productivity. A recent study was conducted using data from 301 coordinated surveys conducted throughout grasslands of various site productivities worldwide 302 (Fraser et al., 2015). The findings of this study supported the pattern of the HBM at regional and 303 global extents. A review study of global scale based on long-term field studies estimated a maximum stimulation of carbon sequestration by forest ecosystem at $\mathrm{N}$ deposition levels between 15 and $35 \mathrm{Kg} \mathrm{N} \mathrm{ha}^{-1} \mathrm{yr}^{-1}$ (De Vries et al., 2014). This is in line with further European studies which report hormetic responses of tree growth to $\mathrm{N}$ deposition (De Vries and Posch, 2011; Braun et al., 2017). There is also evidence for modeled hormetic responses of trees to $\mathrm{N}$ deposition plus $\mathrm{N}$ fixation (De Vries et al., 2017). All these high resolution studies validate the hypothesis that hormesis is not only a phenomenon of individual response to stress but also a phenomenon occurring at different organizational levels like communities or populations

311 (Constantini et al., 2010), thus re-affirming the significance of the phenomenon of hormesis in 312 ecological theory.

\section{Hormesis and competition}

314 Overcompensation stimulatory effects can be a critical driving force in competition when plants 315 compete for light, mineral nutrients, water or space, and may lead to negative effects through 316 trade-offs between survival and reproduction (Calabrese, 1996). In the examples examined here, 317 the metabolic costs for allocating resources to survival (Fig. 4a-e) affected negatively the 318 reproduction (Fig. 4f) of the hybrid larch; however, this was not the case for the co-growing 319 Japanese larch. It should be noted that hybrid larch displays heterosis (Agathokleous et al., 320 2017b; Wang et al., 2018), which was observed in the experiment of Fig. 4 (Sugai et al., 2018).

321 Therefore, hybrid larch followed a competitive strategy in relatively productive and undisturbed 322 vegetation, whereas Japanese larch followed a stress-tolerant strategy (Grime, 1977). It seems 323 hybrid larch, with low capacity for defense against stress, experienced adverse effects in 
324 productive capacity, whereas Japanese larch, with high defense capacity, experienced beneficial 325 effects in productive capacity.

326 Four decades have passed since Grime (1977) suggested the existence of three primary strategies 327 in vascular plants, according to which low stress with low disturbance generates competitive 328 plants; high stress with low disturbance generates stress-tolerant plants; and low stress with high 329 disturbance generates ruderal plants. However, the present review suggests that the CSR Triangle 330 and $\mathrm{R}^{*}$ theories need further examination in relation to the progress of hormesis over time as a 331 potential modifier of competition. Furthermore, does a revisit to the Intermediate Disturbance 332 Hypothesis indicate that it is nothing more, nothing less than hormesis? Nonetheless, the theory 333 of facilitation, which influences community organization (Bruno et al., 2003), may also have 334 implications to hormesis (or hormesis to facilitation) as, for example, in ectomycorrhizal tree species. In turn, hormesis should be implemented within the Menge-Sutherland model.

\section{Hormesis and plasticity}

337 As shown above, hormesis is inseparable from the evolutionary principles of homeostasis and optimization (Rozman and Doull, 2003). Plasticity is 'a basic and primitive biologically selected characteristic' (Calabrese and Mattson, 2011) which links to evolution. Hormesis can provide generalized estimates of biological plasticity (Calabrese and Mattson, 2011). In particular, it can provide quantitative information both for the range of exposure levels at which plants show plastic responses and the lower and upper boundaries for the plastic responses without reproductive costs to the plants (Table 1, Fig. 1). This plasticity underpinning hormesis is evolutionarily critical as it provides evidence for homeostasis and optimization and promotes resilience through adaptation (Fig. 1). Therefore, the hormesis concept should be implemented to truly learn more about 'metabolism, its flexibility, its limits, and its diversity' (Bohnert et al., 1995). Ecotypes could be used for assessment of physiology and fitness traits so as to evaluate the physiological findings of hormesis from ecological viewpoint.

\section{Hormesis and interactions between plants and other organisms}

350 High-level abiotic stress can disrupt the McNew's conceptual model of disease triangle

351 (Chappelka and Grulke, 2016), which shows interactions between the environment, a host and a 352 stressor, and has further relevance to public health (Scholthof, 2007). The evidence provided 353 here indicates that low level stress may also affect the disease triangle. For instance, stimulation 354 of photosynthesis (Figs 2,4) may lead to reduced plant defense against biotic stress as the leaf 355 photosynthetic capacity is negatively correlated with the phenolic pool (Karabourniotis et al., 356 2014), which is important for plant defense against biotic stress. Therefore, the carbon-nutrient 
balance hypothesis along with plant homeostatic features (Hamilton et al., 2001) requires further validation in relation to progressive hormesis.

359 Defensive chemicals produced by plants may induce hormesis in sequestering specialist insects

360 (Ali and Agrawal, 2012). Hormetic-like effects were also recently found in fruit flies (Ceratitis capitata Wiedemann) as a result of exposure to essential oils (limonene) produced by citrus plants (Papanastasiou et al., 2017) and in maize weevil (Sitophilus zeamais Motschulsky) as a result of treatment with essential oils produced by cinnamon (Cinnamomum zeylanicum L), clove (Syzygium aromaticum L.) and tea oil (Melaleuca alternifolia (Maiden \& Betche) Cheel) plants (Haddi et al., 2015; Liao et al., 2016). Hence, changes in chemical constituents of plants as a result of exposure to low level environmental stress may affect plant-insect interactions in a hormetic framework. An example of stimulation by environmental stress is the stimulation of insect nutritional performance which was found when insects were fed with $\mathrm{O}_{3}$-treated leaves (Agathokleous et al., 2017c; Abu ElEla et al., 2018). Furthermore, stress induced by environmental factors may generate biphasic emissions of biogenic volatile organic compounds (VOCs), such as isoprene, suggesting the occurrence of hormesis (Calfapietra et al., 2009; Yuan et al., 2016; Jiang et al., 2017; Tani et al., 2017). VOCs enable a plant-to-plant communication and act as a signal for insect herbivores (Blande et al., 2014). Thus, alteration of VOC emission at low-level exposures of plants to abiotic stressors may alter plant-insect interactions too (Cui et al., 2014, 2016). Similarly to plants, tolerance of insects and nematodes to environmental stress can be achieved by regulating proteins (Cypser and Johnson, 2002; Hayward et al., 2004; Rinehart et al., 2006, 2007; Benoit et al., 2010; Kishimoto et al., 2017; Kumsta and Hansen, 2017; Kumsta et al., 2017). For example, it has been revealed that heat shock proteins, Hsp70 and Hsp90, contributed to the dehydration tolerance of three mosquito species, Aedes aegypti, Anopheles gambiae and Culex pipiens (Benoit et al., 2010). This suggests that the tolerance can be inherited, and thus it would be of utmost importance to study the consequences of hormesis over generations. Support to this assumption is provided by an experiment where the heat-shock factor HSF-1 and the insulin/insulin-like growth factor (IGF) signalling effector DAF-16/FOXO in the parental somatic cells mediated the generation of epigenetic memory in animal biological models which exhibited environmental stress (Kishimoto et al., 2017). It was suggested that the epigenetic memory was "maintained through the histone H3 lysine 4 trimethylase complex in the germline across generations" grown under unstressed conditions (Kishimoto et al., 2017). By using Caenorhabditis elegans as a biological model, it was shown that heat stress in a hormetic 390 framework or HSF-1 overexpression may induce autophagy and reduce accumulation of 
391 polyglutamine (PolyQ) aggregates, and thus contribute to stress tolerance (Kumsta and Hansen,

392 2017; Kumsta et al., 2017). All these lines of evidence suggest that stimulation in the framework

393 of hormesis may lead to enhanced health and tolerance to stress in insects and nematodes.

394 Apart from environmental hormesis in plants, indications for environmental hormesis have been 395 revealed in fungi (mostly upon indirect effects via changes in plants; Manning et al., 1969;

396 Manning and Tiedemann, 1995; McLeod et al., 1988; Paoletti et al., 2007; Mashaheet, 2016),

397 insects (López-Martínez and Hahn, 2012, 2014; López-Martínez et al., 2016a,b), and nematodes

398 (Cypser and Johnson, 2002; Kishimoto et al., 2017; Kumsta and Hansen, 2017; Kumsta et al.,

399 2017). For instance, it has been recently found that the free-living nematode $C$. elegans showed

400 transgenerationally inheritable survival advantages via germline-to-soma communication and 401 autophagy as a result of environmental stress (Kishimoto et al., 2017; Kumsta and Hansen, 2017;

402 Kumsta et al., 2017). Potential biological stimulation of insects, e.g. increased longevity and

403 enhanced sexual performance, by low-level exposures to abiotic factors (López-Martínez and 404 Hahn 2012, 2014; López-Martínez et al., 2014, 2016b) may have implications to biosphere 405 sustainability. Insects may become more tolerant to subsequent exposures to stressors (López406 Martínez and Hahn 2012, 2014; López-Martínez et al., 2014, 2016a,b), i.e. environmental 407 conditioning hormesis, and finally more injurious to plants and their productivity.

\section{Suggestions}

409 Environmental hormesis is a biological phenomenon with relevance not only to toxicology but 410 also to ecology and evolution. Insect-insect, insect-plant and generally trophic interactions may 411 be altered as a result of environmental hormesis.

\section{CONCLUSIONS: THE PATH FORWARD}

413 Plants may display hormetic responses to a variety of environmental factors as a result of 414 physiological or biological stress, and this may affect trophic interactions in highly complex 415 ecosystems.

416 The evidence provided here indicates that response of plants to environmental stimuli should be

417 tested by incorporating the entire exposure-response continuum. In novel experimental setups, it 418 should be tested whether low-level exposure of plants to environmental factors reduces the 419 damage caused by a prior high-level exposure, i.e. environmental postconditioning hormesis.

420 The target of ecotoxicology is communities/populations and not individual organisms, and here it 421 is shown that hormesis can occur at organizational levels beyond the individual level. Therefore, 
422 one challenging task will be to set critical exposure levels for protecting communities and 423 populations when stimulatory responses are taken into account.

424 The present findings support that environmental hormesis is a fundamental biological 425 phenomenon which can occur in nature. Graduate schools at universities should consider 426 implementing environmental hormesis in relevant courses so as to increase the awareness of 427 students regarding the existence of low exposure effects and to contribute in advancing science 428 by new generations of scientists.

429 One of the difficulties will be the required higher number of exposure levels with narrower 430 spacing (Calabrese and Baldwin, 2003c), to effectively identify hormesis and have at least two 431 exposure levels below NOAEL, with consequent large sample size (Calabrese, 1996). Sample 432 size would be further increased if temporal investigations with destructive sampling are taken 433 into account. Importantly, depending on the stressor, investigations of environmental hormesis 434 will require large number of well-replicated experimental units and can be prohibitive in terms of 435 financial costs. Funding agencies and policy makers should consider the importance of such 436 researches in investigating the adaptive mechanisms of vegetation to stress for resilience, 437 ecosystem health and finally biosphere sustainability. Human welfare would also be benefited 438 directly by sustaining natural pharmacological compounds used in medicine and vegetable 439 products of nutritional value and indirectly by sustaining biosphere.

\section{ACKNOWLEDGEMENTS}

441 The author gratefully thanks Prof. Edward J. Calabrese of the School of Public Health and 442 Health Sciences, University of Massachusetts Amherst, USA, for critical comments on an earlier 443 draft. The author wishes to also thank Prof. Takayoshi Koike of the School of Agriculture, 444 Hokkaido University, Japan, for providing raw data upon the author's request to provide all the 445 available unpublished data of Prof. T. Koike's laboratory for examination. He also acknowledges 446 the authors of the original articles for the fundamental contribution in developing these 447 understandings and wants to apologize to authors whose works may have not been cited. 448 Evgenios Agathokleous is an International Research Fellow (ID No: P17102) of the Japan 449 Society for the Promotion of Science (JSPS). This research was supported by JSPS KAKENHI 450 Grant Number JP17F17102. JSPS is a non-profit organization. 


\section{REFERENCES}

Abbas, T., Nadeem, M.A., Tanveer, A., Chauhan, B.S., 2017. Can hormesis of plant-released phytotoxins be used to boost and sustain crop production? Crop. Protect. 93, 69-76.

Abu ElEla, S., Agathokleous, E., Koike, T. (2018). Growth and nutrition of Agelastica coerulea (Coleoptera: Chrysomelidae) larvae fed with leaves obtained from ambient $\mathrm{O}_{3}$ or $\mathrm{O}_{3}-$ enriched atmospheres. Environ. Sci. Poll. Res. Accepted

Agathokleous, E., 2017. Perspectives for elucidating the ethylenediurea (EDU) mode of action for protection against $\mathrm{O}_{3}$ phytotoxicity. Ecotoxicol. Environ. Safe. 142, 530-537.

Agathokleous, E., Saitanis, C.J., Koike, T., 2015. Tropospheric $\mathrm{O}_{3}$, the nightmare of wild plants: A review study. J. Agr. Meteorol. 71, 142-152.

Agathokleous, E., Saitanis, C.J., Wang, X., Watanabe, M., Koike, T., 2016a. A review study on past 40 years of research on effects of tropospheric $\mathrm{O}_{3}$ on belowground structure, functioning and processes of trees: a linkage with potential ecological implications. Wat. Air Soil Poll. 227, 33.

Agathokleous, E., Mouzaki-Paxinou, A.-C., Saitanis, C.J., Paoletti, E., Manning, W.J., 2016b. The first toxicological study of the antiozonant and research tool ethylenediurea (EDU) using a Lemna minor L. bioassay: Hints to its mode of action. Environ. Pollut. 213, 996-1006.

Agathokleous, E., Saitanis, C.J., Burkey, K.O., Ntatsi, G., Vougeleka, V., Mashaheet, A.S.M., Pallides, A., 2017a. Application and further characterization of the snap bean S156/R123 ozone biomonitoring system in relation to ambient air temperature. Sci. Total Environ. 580, 1046-1055.

Agathokleous, E., Vanderstock, A., Kita, K., Koike, T., 2017b. Stem and crown growth of Japanese larch and its hybrid $\mathrm{F}_{1}$ grown in two soils and exposed to two free-air $\mathrm{O}_{3}$ regimes. Environ. Sci. Poll. Res. 24, 6634-6647.

Agathokleous, E., Sakikawa, T., Abu El-Ela, S.I., Mochizuki, T., Nakamura, M., Watanabe, M., Kawamura, K., and Koike, T. (2017c). Ozone alters the feeding behavior of the leaf beetle Agelastica coerulea (Coleoptera: Chrysomelidae) into leaves of Japanese white birch (Betula platyphylla var. japonica). Environ. Sci. Poll. Res. 24, 17577-17583.

Agren, G.I., Franklin, O., 2003. Root:shoot ratios, optimization and nitrogen productivity. Ann. Bot. 92, 795-800.

Ainsworth, E.A., Yendrek, C.R., Sitch, S., Collins, W.J., Emberson, L.D., 2012. The effects of tropospheric ozone on net primary productivity and implications for climate change. Annu. Rev. Plant Biol., 63, 637-661. 
Ali, J.G., Agrawal, A.A., 2012. Specialist versus generalist insect herbivores and plant defense. Trends Plant Sci. 17, 293-302.

Ali, A., Ong, M.K, Forney, C.F., 2014. Effect of ozone pre-conditioning on quality and antioxidant capacity of papaya fruit during ambient storage. Food Chem. 142, 19-26.

Aliferis, K.A., Jabaji, S., 2011. Metabolomics - A robust bioanalytical approach for the discovery of the modes-of-action of pesticides: A review. Pestic. Biochem. Phys. 100, 105-117.

Belz, R.G., Piepho, H.P., 2013. Variability of hormetic dose responses of the antiauxin PCIB on Lactuca sativa in a plant bioassay. Weed Res. 53, 418-428.

Belz, R.G., Cedergreen, N., Sørensen, H., 2008. Hormesis in mixtures - Can it be predicted? Sci. Total. Environ. 404, 77-87.

Benoit, J.B., López-Martínez, G., Phillips, Z.P., Patrick, K.R., Denlinger, D.L., 2009. Heat shock proteins contribute to mosquito dehydration tolerance. J. Insect Physiol. 56, 151-156.

Blande, J.D., Holopainen, J.K., Niinemets, Ü., 2014. Plant volatiles in polluted atmospheres: stress responses and signal degradation. Plant Cell Environ. 37, 1892-1904.

Bijlsma, R., Loeschcke, V., 2005. Environmental stress, adaptation and evolution: an overview. J. Evol. Biol. 18, 744-749.

Bocci, V., Borrelli, E., Travagli, V., Zanardi, I., 2009. The ozone paradox: ozone is a strong oxidant as well as a medical drug. Med. Res. Rev. 29, 646-682.

Bohnert, H.J, Nelson, D.E, Jensen, R.G., 1995. Adaptations to environmental stresses. The Plant Cell 7, 1099-1111.

Braun, S., Flückiger, W., 1989. Effect of ambient ozone and acid mist on aphid development. Environ. Pollut. 56, 177-187.

Braun, S., Schindler, C., Rihm, B., 2017. Growth trends of beech and Norway spruce in Switzerland: The role of nitrogen deposition, ozone, mineral nutrition and climate. Sci. Total Environ. 599-600, 637-646.

Bruno, J.F., Stachowicz, J.J., Bertness, M.D., 2003. Inclusion of facilitation into ecological theory. TRENDS Ecol. Evol. 18, 119-125.

Calabrese, E.J., 1996. Expanding the RfD concept to incorporate and optimize beneficial effects while preventing toxic responses from nonessential toxicants. Ecotox. Environ. Safe. 34, 94-101.

Calabrese, E.J., 2001. Overcompensation stimulation: a mechanism for hormetic effects. Cr. Rev. Toxicol. 31, 425-470.

Calabrese, E.J., 2003. The maturing of hormesis as a credible dose-response model. DoseResponse 1, 319-343. 
Calabrese, E.J., 2004. Hormesis: from marginalization to mainstream. A case for hormesis as the default dose-response model in risk assessment. Toxicol. Appl. Pharmacol. 197, 125-136.

Calabrese, E.J., 2005. Paradigm lost, paradigm found: The re-emergence of hormesis as a fundamental dose response model in the toxicological sciences. Environ. Pollut. 138, 378-411.

Calabrese, E.J., 2009. The road to linearity: why linearity at low doses became the basis for carcinogen risk assessment. Arch. Toxicol. 83, 203-225.

Calabrese, E.J., 2011. Toxicology rewrites its history and rethinks its future: giving equal focus to both harmful and beneficial effects. Environ. Toxicol. Chem. 30, 2658-2673.

Calabrese, E.J., 2013a. How the US National Academy of Sciences misled the world community on cancer risk assessment: new findings challenge historical foundations of the linear dose response. Arch. Toxicol. 87, 2063-2081.

Calabrese, E.J., 2013b. Biphasic dose responses in biology, toxicology and medicine: Accounting for their generalizability and quantitative features. Environ. Pollut. 182, 452-460.

Calabrese, E.J., 2014. Hormesis: a fundamental concept in biology. Microb. Cell 1, 145-149.

Calabrese, E.J., 2015. Hormesis: principles and applications. Homeopathy 104, 69-82.

Calabrese, E.J., 2016. The emergence of the dose-response concept in biology and medicine. Int. J. Mol. Sci. 17, 2034.

Calabrese, E.J., 2016b. Pre- and post-conditioning hormesis in elderly mice, rats, and humans: its loss and restoration. Biogerontology 17, 681-702.

Calabrese, E.J., 2017a. The threshold vs LNT showdown: Dose rate findings exposed flaws in the LNT model part 1. The Russell-Muller debate. Environ. Res. 154, 435-451.

Calabrese, E.J., 2017b. The threshold vs LNT showdown: Dose rate findings exposed flaws in the LNT model part 2. How a mistake led BEIR I to adopt LNT. Environ. Res. 154, 452-458.

Calabrese, E.J., Baldwin, L.A., 2000a. The marginalization of hormesis. Hum. Exp. Toxicol. $19,32-40$.

Calabrese, E.J., Baldwin, L.A., 2000b. Tales of two similar hypotheses: the rise and fall of chemical and radiation hormesis. Hum. Exp. Toxicol. 19, 85-97.

Calabrese, E.J., Baldwin, L.A., 2000c. Radiation hormesis: the demise of a legitimate hypothesis. Hum. Exp. Toxicol. 19, 76-84.

Calabrese, E.J., Baldwin, L.A., 2000d. Radiation hormesis: its historical foundations as a biological hypothesis. Hum. Exp. Toxicol. 19, 41-75.

Calabrese, E.J., Baldwin, L.A., 2000e. Chemical hormesis: its historical foundations as a biological hypothesis. Hum. Exp. Toxicol. 19, 2-31. 
551

552

553

554

555

556

557

558

559

560

561

562

563

564

565

566

567

568

569

570

571

572

573

574

575

576

577

578

579

580

581

582

583

Calabrese, E.J., Baldwin, L.A., 2001. Hormesis: U-shaped dose responses and their centrality in toxicology. Trends Pharmacol. Sci. 22, 285-291.

Calabrese, E.J., Baldwin, L.A., 2002. Hormesis and high-risk groups. Regul. Toxicol. Pharm. $35,414-428$.

Calabrese, E.J., Baldwin, L.A., 2003a. Toxicology rethinks its central belief. Nature 421, 691-692.

Calabrese, E.J., Baldwin, L.A., 2003b. The hormetic dose-response model is more common than the threshold model in toxicology. Toxicol. Sci. 71, 246-250.

Calabrese, E.J., Baldwin, L.A., 2003c. Hormesis: The dose-response revolution. Annu. Rev. Pharmacol. Toxicol. 43, 17-5197.

Calabrese, E.J., Blain, R.B., 2005. The occurrence of hormetic dose responses in the toxicological literature, the hormesis database: an overview. Toxicol. Appl. Pharm. 202, 289-301. Calabrese, E.J., Blain, R.B., 2009. Hormesis and plant biology. Environ. Pollut.157, 42-48.

Calabrese, E.J., Blain, R.B., 2011. The hormesis database: The occurrence of hormetic dose responses in the toxicological literature. Reg. Toxicol. Pharmacol. 61 73-81.

Calabrese, E.J., Mattson, M.P., 2011. Hormesis provides a generalized quantitative estimate of biological plasticity. J. Cell Comm. Signal. 5, 25-38.

Calabrese, E.J., Baldwin, L.A., Holland, C.D., 1999. Hormesis: A highly generalizable and reproducible phenomenon with important implications for risk assessment. Risk Anal. 19, 261281.

Calabrese, E.J., Bachmann, K.A., Bailer, A.J., et al., 2007. Biological stress response terminology: Integrating the concepts of adaptive response and preconditioning stress within a hormetic dose-response framework. Toxicol. Appl. Pharm. 222, 122-128.

Calatayud, V., Cerveró, J., Calvo, E., García-Breijo, F.-J., Reig-Armiñana, J., Sanz, M.J., 2011. Responses of evergreen and deciduous Quercus species to enhanced ozone levels. Environ. Pollut. 159, 55-63.

Calfapietra, C., Fares, S., Loreto, F., 2009. Volatile organic compounds from Italian vegetation and their interaction with ozone. Environ. Pollut. 157, 1478-1486.

Carriero, G., Brunetti, C., Fares, S., Hayes, F., Hoshika, Y., Mills, G., Tattini, M., Paoletti, E., 2016. BVOC responses to realistic nitrogen fertilization and ozone exposure in silver birch. Environ. Pollut. 213, 988-995.

Cedergreen, N., Streibig, J.C., Kudsk, P., Mathiassen, S.K., Duke, S.O., 2007. The occurrence of hormesis in plants and algae. Dose-Response 5, 150-162. 
Cedergreen, N., Ritz, C., Streibig, J.C., 2005. Improved empirical models describing hormesis. Environ. Toxicol. Chem. 24, 3166-3172.

Chappelka, A.H., Grulke, N.E., 2016. Disruption of the 'disease triangle' by chemical and physical environmental change. Plant Biol. 18, 5-12.

Constantini, D., Metcalfe, N.B., Monanghan, P., 2010. Ecological processes in a hormetic framework. Ecol. Lett. 13, 1435-1447.

Cook, R., Calabrese, E.J., 2006. The importance of hormesis to public health. Env. Health Perspect. 114, 1631-1635.

592

Coyne, P.I., Bingham, G.E., 1978. photosynthesis and stomatal light responses in snap beans exposed to hydrogen sulfide and ozone. J. Air Pollut. Con. Assoc. 28, 1119-1123.

Cui, H., Su, J., Wei, J., Hu, Y., Ge, F., 2014. Elevated $\mathrm{O}_{3}$ enhances the attraction of whiteflyinfested tomato plants to Encarsia formosa. Sci. Rep. 4, 5350.

Cui, H., Su, J., Wei, J., Li, C., Ge, F., 2014. Elevated $\mathrm{O}_{3}$ increases volatile organic compounds via jasmonic acid pathway that promote the preference of parasitoid Encarsia formosa for tomato plants. Plant Sci. 253, 243-250.

Cypser, J.R., Johnson, T.E., 2002. Multiple stressors in Caenorhabditis elegans induce stress hormesis and extended longevity. J. Gerontol. A Biol. Sci. Med. Sci. 57, B109-14.

D’Angiolillo, F., Tonelli, M., Pellegrini, E., Nali, C., Lorenzini, G., Pistelli, L., Pistelli, L., 2015. Can ozone alter the terpenoid composition and membrane integrity of in vitro Melissa officinalis shoots? Nat. Prod. Comm. 10, 1055-1058.

Darrall, N.M., 1989. The effect of air pollutants on physiological processes in plants. Plant Cell Environ. 12, 1-30.

Darvill, A.G., Albersheim, P., 1987. Phytoalexins and their elicitors-a defense against microbial infection in plants. Ann. Rev. Plant Physiol. 35, 243-275.

608

De Marco, A., Screpanti, A., Attorre, F., Proietti, C., Vitale, M., 2013. Assessing ozone and nitrogen impact on net primary productivity with a Generalised non-Linear Model. Environ. Pollut. 172, 250-263.

De Vries, W., Posch, M., 2011. Modelling the impact of nitrogen deposition, climate change and nutrient limitations on tree carbon sequestration in Europe for the period 1900-2050. Environ. Pollut. 159, 2289-2299.

614 De Vries, W., Du, E., Butterbach-Bahl, K., 2014. Short and long-term impacts of nitrogen 615 deposition on carbon sequestration by forest ecosystems. Curr. Opin. Environ. Sustain. 9-10, 90616104. 
De Vries, W., Posch, M., Simpson, D., Reinds, G.J., 2017. Modelling long-term impacts of changes in climate, nitrogen deposition and ozone exposure on carbon sequestration of European forest ecosystems. Sci. Total. Environ. 605-606, 1097-1116.

De Vries, W., Dobbertin, M.H., Solberg, S., van Dobben, H.F., Schaub, M., 2014. Impacts of acid deposition, ozone exposure and weather conditions on forest ecosystems in Europe: an overview. Plant Soil 380, 1-45.

Döring, A.S., Pellegrini, E., Campanella, A., Trivellini, A., Gennai, C., Petersen, M., Nali, C., Lorenzini, G., 2013, How sensitive is Melissa officinalis to realistic ozone concentrations? Plant Physiol. Bioch. 74, 156-164.

Doss, M., 2013. Linear no-threshold model vs. radiation hormesis. Dose-Response 11, 480497.

Eamus, D., Barnes, J.D., Mortensen, L., Ro-Poulsen, H., Davison, A.W., 1990. Persistent stimulation of $\mathrm{CO}_{2}$ assimilation and stomatal conductance by summer ozone fumigation in Norway spruce. Environ. Pollut. 63, 365-379.

Elliott, K.C., 2011. Is a Little Pollution Good for You? Incorporating Societal Values in Environmental Research, Oxford University Press, 246pp.

Emberson, L.D., Ashmore, M.R., Murray, F., et al., 2001. Impacts of air pollutants on vegetation in developing countries. Wat. Air Soil Pol. 130, 107-118.

Felzer, B.S., Cronin, T., Reilly, J.M., Melillo, J.M., Wang, X., 2007. Impacts of ozone on trees and crops. C. R. Geoscience 339, 784-798.

Feng, Z., Kobayashi, K., Ainsworth, E.A., 2008a. Impact of elevated ozone concentration on growth, physiology, and yield of wheat (Triticum aestivum L.): a meta-analysis. Global Chang. Biol. 14, 2696-2708.

Feng, Z.-Z., Zeng, H.-Q., Wang, X.-K., Zheng, Q.-W., Feng, Z.-W., 2008b. Sensitivity of Metasequoia glyptostroboides to ozone stress. Photosynthetica 46, 463-465.

Feng, Z., Hu, E., Wang, X., Jiang, L., Liu, X., 2015. Ground-level $\mathrm{O}_{3}$ pollution and its impacts on food crops in China: A review. Environ. Pollut. 199, 42-48.

Ferretti, M., Fagnano, M., Amoriello, T., et al., 2007. Measuring, modelling and testing ozone exposure, flux and effects on vegetation in southern European conditions - What does not work? A review from Italy. Environ. Pollut. 146, 648-658.

Fiscus, E.L., Booker, F.L., Burkey, K.O., 2005. Crop responses to ozone: uptake, modes of 648 action, carbon assimilation and partitioning. Plant Cell Environ. 28, 997-1011. 
Flowers, M.D., Fiscus, E.L., Burkey, K.O., Booker, F.L., Dubois, J.-J.B., 2007. Photosynthesis, chlorophyll fluorescence, and yield of snap bean (Phaseolus vulgaris L.) genotypes differing in sensitivity to ozone. Environ. Exp. Bot. 61, 190-198.

Fornes, F., Belda, R.M., Carrión, C., Noguera, V., García-Agustín, P., Abad, M., 2007. Presalinity tolerance. Sci. Hort. 113, 52-59.

Franzaring, J., Hartmann, A., Slowik, F., Fangmeier, A., 2013. Effects of tropospheric ozone on the bioenergy plants Sida hermaphrodita L. Rusby and Silphium perfoliatum L, in: Mills, G., Wagg, S., Harmens, H. (Eds.), Ozone Pollution: Impacts on ecosystem services and biodiversity. ICP Vegetation Programme Coordination Centre, Centre for Ecology and Hydrology, Bangor, pp. 79-81.

Fraser, L.H., Pitcher, J., Jentsch, A., et al., 2015. Worldwide evidence of a unimodal relationship between productivity and plant species richness. Science 349, 302-305.

Grantz, D.A., Gunn, S., Vu, H.-B., 2006. $\mathrm{O}_{3}$ impacts on plant development: a meta-analysis of root/shoot allocation and growth. Plant Cell Environ. 29, 1193-1209.

Gray, D.E., Pallardy, S.G., Garrett, H.E., Rottinghaus, G.E., 2003. Effect of acute drought stress and time of harvest on phytochemistry and dry weight of St. John's wort leaves and flowers. Plant Med. 69, 1024-1030.

Grayer, R.J., Kokubun, T., 2001. Plant-fungal interactions: the search for phytoalexins and other antifungal compounds from higher plants. Phytochemistry 56, 253-263.

Grime, J.P., 1973. Control of species density in herbaceous vegetation. J. Environ. Manag. 1, 151-167.

Grime, J.P., 1977. Evidence for the existence of three primary strategies in plants and its relevance to ecological and evolutionary theory. The Am. Nat. 111, 1169-1194.

Grime, J.P., 1979. Plant Strategies, Vegetation Processes and Ecosystem Properties, 1st edition, p. 417. Wiley, Chichester.

Grime, J.P., 2001. Plant Strategies, Vegetation Processes and Ecosystem Properties, 2nd edition, p. 417. Wiley, Chichester.

Hadacek, F., Bachmann, G., Engelmeier, D., Chobot, V., 2011. Hormesis and a chemical raison d'être for secondary plant metabolites. Dose-Response 9, 79-116.

Haddi, K., Oliveira, E.E., Faroni, L.R., Guedes, D.C., Miranda, N.N., 2015. Sublethal exposure to clove and cinnamon essential oils induces hormetic-like responses and disturbs 681 behavioral and respiratory responses in Sitophilus zeamais (Coleoptera: Curculionidae). J. Econ. 
683

684

685

686

687

688

689

690

691

692

693

694

695

696

697

698

699

700

701

702

703

704

705

706

707

708

709

710

711

712

713

714

715

716

Hamilton, J.G., Zangerl, A.R., DeLucia, E.H., Berenbaum, M.R., 2001. The carbon-nutrient balance hypothesis: its rise and fall. Ecol. Let. 4, 86-95.

Hammerschmidt, R., 1999. PHYTOALEXINS : What have we learned after 60 years? Ann. Rev. Phytopathol. 37, 285-306.

Hayward, S.A.L., Rinehart, J.P., Denlinger, D.L., 2004. Desiccation and rehydration elicit distinct heat shock protein transcript responses in flesh fly pupae. The J. Exp. Biol. 207, 963-971.

Hernández, I., Alegre, L., Munné-Bosch, S., 2004. Drought-induced changes in flavonoids and other low molecular weight antioxidants in Cistus clusii grown under Mediterranean field conditions. Tree Physiol. 24, 1303-1311.

Hong, B.G., Lee, K.J., 2001. Interaction of ozone with simultaneous water deficit and water deficit preconditioning in one-year-old Pinus densiflora seedlings. J. For. Res. 6, 273-279.

Horgan, R.P., Kenny, L.C., 2011. 'Omic' technologies: genomics, transcriptomics, proteomics and metabolomics. The Obstetr. Gynaecol. 13, 189-195.

Hoshika, Y., Tatsuda, S., Watanabe, M., Wang, X., Watanabe, Y., Saito, H., Koike, T., 2013. Effect of ambient ozone at the somma of Lake Mashu on growth and leaf gas exchange in Betula ermanii and Betula platyphylla var. japonica. Environ. Exp. Bot. 90, 12-16.

Izuta, T., Yamaoka, T., Nakaji, T., Yonekura, T., Yokoyama, M., Funada, R., Koike, T., Totsuka, T., 2004. Growth, net photosynthesis and leaf nutrient status of Fagus crenata seedlings grown in brown forest soil acidified with $\mathrm{H}_{2} \mathrm{SO}_{4}$ or $\mathrm{HNO}_{3}$ solution. Trees 18, 677-685.

Jacometti, M.A., Wratten, S.D., Walter, M., 2009. Review: Alternatives to synthetic fungicides for Botrytis cinerea management in vineyards. Aus. J. Grape Wine Res. 16, 154-172.

Jiang, Y., Ye, J., Li, S., Niinemets, Ü., 2017. Methyl jasmonate-induced emission of biogenic volatiles is biphasic in cucumber: a high-resolution analysis of dose dependence. J. Exp. Bot. 68, 4679-4694.

Kacienè, G., Žaltauskaitè, J., Milčè, E., Juknys, R., 2015. Role of oxidative stress on growth responses of spring barley exposed to different environmental stressors. J. Plant Ecol. 8, 605-616.

Karabourniotis, G., Liakopoulos, G., Nikolopoulos, D., Bresta, P., Stavroulaki, V., Sumbele, S., 2014. "Carbon gain vs. water saving, growth vs. defence": Two dilemmas with soluble phenolics as a joker. Plant Sci. 227, 21-27.

Karlsson, P.E., Uddling, J., Braun, S., et al., 2004. New critical levels for ozone effects on young trees based on AOT40 and simulated cumulative leaf uptake of ozone. Atmos. Environ. $38,2283-2294$.

Kintzios, S.E., 2006. Terrestrial plant-derived anticancer agents and plant species used in anticancer research. Crit. Rev. Plant Sci. 25, 79-113. 
Kishimoto, S., Uno, M., Okabe, E., Nono, M., Nishida, E., 2017. Environmental stresses induce transgenerationally inheritable survival advantages via germline-to-soma communication in Caenorhabditis elegans. Nature. Comm. 8, 14031.

Kitao, M., Yasuda, Y., Kominami, Y., Yamanoi, K., Komatsu, M., Miyama, T., Mizoguchi, Y., Kitaoka, S., Yazaki, K., Tobita, H., Yoshimura, K., Koike, T., Izuta, T., 2016. Increased phytotoxic $\mathrm{O}_{3}$ dose accelerates autumn senescence in an $\mathrm{O}_{3}$-sensitive beech forest even under the present-level $\mathrm{O}_{3}$. Sci. Rep. 6, 32549.

Kleiber, T., Borowiak, K., Schroeter-Zakrzewska, A., Budka, A., Osiecki, S., 2017. Effect of ozone treatment and light colour on photosynthesis and yield of lettuce. Sci. Hort. 217, 130-136.

Kress, L.W., Skelly, J.M., 1982. Response of several eastern forest tree species to chronic doses of ozone and nitrogen dioxide. Plant Dis. 66, 1149-1152.

Kuć, K., 1995. Phytoalexins, stress metabolism, and disease resistance in plants. Ann. Rev. Phytopathol. 33, 275-297.

Kumsta, C., Hansen, M., 2017. Hormetic heat shock and HSF-1 overexpression improve $C$. elegans survival and proteostasis by inducing autophagy. Autophagy 13, 1076-1077.

Kumsta, C., Chang, J.T., Schmalz, J., Hansen, M., 2017. Hormetic heat stress and HSF-1 induce autophagy to improve survival and proteostasis in C. elegans. Nat Commun. 8, 14337.

Larcher, W., 2003. Physiological plant ecology. 4 ed. Springer, Berlin, pp. 513.

Leone, I.A., Brennan, E., 1975. Variable effects of ozone on pinto bean internodes. Phytopathology 65, 666-669.

Li, B., Wang, W., Zong, Y., Qin, G., Tian, S., 2012. Exploring pathogenic mechanisms of Botrytis cinerea secretome under different ambient $\mathrm{pH}$ based on comparative proteomic analysis. J. Prot. Res. 11, 4249-4260.

Li, S., Harley, P.C., Niinemets, Ü., 2017. Ozone-induced foliar damage and release of stress volatiles is highly dependent on stomatal openness and priming by low-level ozone exposure in Phaseolus vulgaris. Plant Cell Environ. 40, 1984-2003.

Liao, M., Xiao, J.-J., Zhou, L.-J., Liu, Y., Wu, X.-W., Hua, R.-M., Wang, G.-R., Cao, H.-Q., 2016. Insecticidal activity of Melaleuca alternifolia essential oil and RNA-Seq analysis of Sitophilus zeamais transcriptome in response to oil fumigation. PLoS ONE 11, e0167748.

Lindroth, R.L., 2010. Impacts of elevated atmospheric $\mathrm{CO}_{2}$ and $\mathrm{O}_{3}$ on forests: phytochemistry, trophic interactions, and ecosystem dynamics. J. Chem. Ecol. 36, 2-21. 
López-Martínez, G., Hahn, D.A., 2012. Short-term anoxic conditioning hormesis boosts antioxidant defenses, lowers oxidative damage following irradiation and enhances male sexual performance in the Caribbean fruit fly, Anastrepha suspensa. J. Exp. Biol. 215, 2150-2161.

López-Martínez, G., Hahn, D.A., 2014. Early life hormetic treatments decrease irradiationinduced oxidative damage, increase longevity, and enhance sexual performance during old age in the Caribbean fruit fly. Plos One 9, e88128.

López-Martínez, G., Carpenter, J.E., Hight, S.D., Hahn, D.A., 2014. Low-oxygen atmospheric treatment improves the performance of irradiation-sterilized male cactus moths used in SIT. J. Econ. Entom. 107, 185-197.

López-Martínez, G., Meagher, R.L., Jeffers, L.A., Bailey, W.D., Hahn, D.A., 2016a. Low oxygen atmosphere enhances post-irradiation survival of Trichoplusia ni (Lepidoptera: Noctuidae). Florida Entom. 99, 24-33.

López-Martínez, G., Carpenter, J.E., Hight, S.D., Hahn, D.A., 2016b. Anoxia-conditioning hormesis alters the relationship between irradiation doses for survival and sterility in the cactus moth, Cactoblastis cactorum (Lepidoptera: Pyralidae). Florida Entom. 99, 95-104.

Luckey, T.D., Lawrence, K.S., 2006. Radiation hormesis: the good, the bad, and the ugly. Dose-Response 4, 169-190.

Luo, Z.B., Janz, D., Jiang, X., Gobel, C., Wildhagen, H., Tan, Y., Rennenberg, H., Feussner, I., Polle, A., 2009. Upgrading root physiology for stress tolerance by ectomycorrhizas: insights from metabolite and transcriptional profiling into reprogramming for stress anticipation. Plant Physiol. 151, 1902-1917.

Manning, W.J., 2005. Invited review. Environ. Pollut. 138, 377.

Manning, W.J., Feder, W.A., Perkins, I., 1969. Ozone injury increases infection of geranium leaves by Botrytis cinerea. 60, 669-670.

Manning, W.J., Tiedemann, A.V., 1995. Climate change: Potential effects of increased atmospheric carbon dioxide $\left(\mathrm{CO}_{2}\right)$, ozone $\left(\mathrm{O}_{3}\right)$, and ultraviolet-B (UV-B) radiation on plant diseases. Environ. Pollut. 88, 219-245.

Martínez-Romero, D., Bailén, G., Serrano, M., Guillén, F., Valverde, J.M., Zapata, P., Castillo, S., Valero, D., 2007. Tools to maintain postharvest fruit and vegetable quality throughthe inhibition of ethylene action: a review. Crit. Rev. Food Sci. Nutr. 47, 543-560. 
Marzuoli, R., Finco, A., Chiesa, M., Gerosa, G., 2017. A dose-response relationship for marketable yield reduction of two lettuce (Lactuca sativa L.) cultivars exposed to tropospheric ozone in Southern Europe. Environ. Sci. Pollut. Res. DOI 10.1007/s11356-016-8224-6

Mashaheet, A.M.S., Marshall, D.S., Burkey, K.O., 2015. Yield components of winter wheat as affected by leaf rust disease under elevated $\mathrm{CO}_{2}$ and/or $\mathrm{O}_{3}$. In: ICP Vegetation $28^{\text {th }}$ Task Force Meeting 3-5 February 2015, Rome, Italy: Programme and Abstracts. Centre for Ecology and Hydrology, Bangor, p38.

Mashaheet, A.M.S., 2016. Effects of near-ambient $\mathrm{O}_{3}$ and $\mathrm{CO}_{2}$ on wheat performance and interactions with leaf and stem rust pathogens. 180p. North Carolina State University, Raleigh, USA. (PhD thesis) https://repository.lib.ncsu.edu/handle/1840.20/33361.

Matyssek, R., Kozovits, A.R., Wieser, G., 2015. Vegetation response to climate change and air pollution - unifying research and evidence from northern and southern hemisphere. Environ. Pollut. 196, 480-482.

McDonnell, M.J., Hahs, A.K., 2015. Adaptation and adaptedness of organisms to urban environments. Annu. Rev. Ecol. Evol. Syst. 46, 261-280.

McLeod, A.R., Roberts, T.M., Alexander, K., Cribb, D.M., 1988. Effects of open-air fumigation with sulphur dioxide on the growth and yield of winter barley. New Phytol. 109, 6778.

Mills, G., Buse, A., Gimeno, B., Bermejo, V., Holland, M., Emberson, L., Pleijel, H., 2007. A synthesis of AOT40-based response functions and critical levels of ozone for agricultural and horticultural crops. Atmos. Environ. 41, 2630-2643.

Minas, I.S., Vicente, A.R., Dhanapal, A.P., Manganaris, G.A., Goulas, V., Vasilakakis, M., Crisosto, C.H., Molassiotis, A., 2014. Ozone-induced kiwifruit ripening delay is mediated by ethylene biosynthesis inhibition and cell wall dismantling regulation. Plant Sci. 229, 76-85.

Moustakas, M., Malea, P., Haritonidou, K., Sperdouli, I., 2017. Copper bioaccumulation, photosystem II functioning, and oxidative stress in the seagrass Cymodocea nodosa exposed to copper oxide nanoparticles. Environ. Sci. Pollut. Res. Int. 24, 16007-16018.

Munné-Bosch, S., 2005. The role of $\alpha$-tocopherol in plant stress tolerance. J. Plant Physiol. $162,743-748$.

Mushak, P., 2016. Temporal stability of chemical hormesis (CH): Is $\mathrm{CH}$ just a temporary stop on the road to thresholds and toxic responses? Sci. Total. Environ. 569-570, 1446-1456. 
Myers, S.S., Zanobetti, A., Kloog, I., et al., 2014. Increasing $\mathrm{CO}_{2}$ threatens human nutrition. Nature 510, 139-142.

811 Nali, C., Ferretti, M., Pellegrini, M., Lorenzini, G., 2001. Monitoring and biomonitoring of surface ozone in Florence, Italy. Environ. Mon. Assess. 69, 159-174.

Navarro García, A., del Pilar Bañón Árias, S., Morte, A., Sánchez-Blanco, M., 2011. Effects of nursery preconditioning through mycorrhizal inoculation and drought in Arbutus unedo L. plants. Mycorrhiza 21, 53-64.

Nikolova, P.S., Andersen, C.P., Blaschke, H., Matyssek, R., Häberle, K.-H., 2010. Belowground effects of enhanced tropospheric ozone and drought in a beech/spruce forest (Fagus sylvatica L./Picea abies [L.] Karst). Environ. Pollut. 158, 1071-1078.

Okano, K., Totsuka, T., Fukuzawa, T., Tazaki, T., 1985. Growth responses of plants to various concentrations of nitrogen dioxide. Environ. Pollut. 38, 361-373.

Oksanen, E., Pandey, V., Keski-Saari, S., Kontunen-Soppela, S., Sharma, C., 2013. Impacts of increasing ozone on Indian plants. Environ. Pollut. 177, 189-200.

Ovize, M., Baxter, G.F., Di Lisa, F., Ferdinandy, P., Garcia-Dorado, D., Hausenloy, D.J., Heusch, G., Vinten-Johansen, J., Yellon, D.M., Schulz, R., 2010. Postconditioning and protection from reperfusion injury: where do we stand? Cardiov. Res. 87, 406-423.

Pääkköönen, E., Vahala, J., Holopainen, T., Karjalainen, R., Kärenlampi, L., 1996. Growth responses and related biochemical and ultrastructural changes of the photosynthetic apparatus in birch (Betula pendula) saplings exposed to low concentrations of ozone. Tree Physiol. 16, 597605.

Paoletti, E., Anselmi, N., Franceschini, A., 2007. Pre-exposure to ozone predisposes oak leaves to attacks by Diplodia corticola and Biscogniauxia mediterranea. Sci. World J. 7, 222230.

Papanastasiou, S.A., Bali, E.-M.D., Ioannou, C.S., Papachristos, D.P., Zarpas, K.D., 834 Papadopoulos, N.T., 2017. Toxic and hormetic-like effects of three components of citrus essential oils on adult Mediterranean fruit flies (Ceratitis capitata). PLoS ONE 12, e0177837.

Paracelsus (Theophrastus ex Hohenheim Eremita): Von der Besucht. Dillingen. 1567.

Piironen, V., Lindsay, D.G., Miettinen, T.A., Toivo, J., Lampi, A.-M., 2000. Plant sterols: biosynthesis, biological function and their importance to human nutrition. J. Sci. Food Agric. 80, 939-966.

840 Poschenrieder, C., Cabot, C., Martos, S., Gallego, B., Barceló, J., 2013. Do toxic ions induce 841 hormesis in plants? Plant Sci. 212, 15-25. 
Ranieri, A., Castagna, A., Soldatini, G.F., 2000. Differential stimulation of ascorbate peroxidase isoforms by ozone exposure in sunflower plants. J. Plant Physiol. 156, 266-271.

Rattan, S.I., 2008. Hormesis in aging. Ageing Res. Rev. 7, 63-78.

Rice, R.G., 2002. Century 21 - pregnant with ozone, Ozone Sci. Eng. 24, 1-15.

Rinehart, J.P., Robich, R.M., Denlinger, D.L., 2006. Enhanced cold and desiccation tolerance in diapausing adults of Culex pipiens, and a role for Hsp70 in response to cold shock but not as a component of the diapause program. J. Med. Entomol. 43, 713-22.

Rinehart, J.P., Li, A., Yocum, G.D., Robich, R.M., Hayward, S.A.L., Denlinger, D.L., 2007. Up-regulation of heat shock proteins is essential for cold survival during insect diapause. PNAS 104, 11130-11137.

Roberts, T.M., 1984. Effects of air pollutants on agriculture and forestry. Atmos. Environ. 18, 629-652.

Rozman, K.K., Doull, J., 2003. Scientific foundations of hormesis. Part 2. Maturation, strengths, limitations, and possible applications in toxicology, pharmacology, and epidemiology. Cr. Rev. Toxicol. 33, 451-462.

Rozpadek, P., Slesak, I., Cebula, S., Waligorski, P., Dziurka, M., Skoczowski, A., Miszalski, Z., 2013. Ozone fumigation results in accelerated growth and persistent changes in the antioxidant system of Brassica oleracea L. var. capitata f. alba. J. Plant Physiol. 170, 1259-1266.

Rozpadek, P., Nosek, M., Slesak, I., Kunicki, E., Dziurka, M., Miszalski, Z., 2015. Ozone fumigation increases the abundance of nutrients in Brassica vegetables: broccoli (Brassica oleracea var. italica) and Chinese cabbage (Brassica pekinensis). Eur. Food. Res. Technol. 240, 459-462.

Ruiz-Sánchez, M.C., Domingo, R., Torrecillas, A., Pérez-Pastor, A., 2000. Water stress preconditioning to improve drought resistance in young apricot plants. Plant Sci. 156, 245-251.

Saitanis, C., 2008. Tropospheric ozone: a menace for crops and natural vegetation in Greece. Ital. J. Agron. / Riv. Agron. 1, 71-77.

Sanders, G.E., Robinson, A.D., Geissler, P.A., Colls, J.J., 1992. Yield stimulation of a commonly grown cultivar of Phaseolus vulgaris L. at near-ambient ozone concentrations. New Phytol. 122, 63-70.

Sanz, J., Gonzalez-Fernandez, I., Elvira, S., Muntifering, R., Alonso, R., Bermejo-Bermejo, V., 2016. Setting ozone critical levels for annual Mediterranean pasture species: Combined analysis of open-top chamber experiments. Sci. Total. Environ. 571, 670-679.

Scholthof, K.-B.G., 2007. The disease triangle: pathogens, the environment and society. Nat. Rev. Microbiol. 5, 152-156. 
Segade, S.R., Vilanova, M., Giacosa, S., Perrone, I., Chitarra, W., Pollon, M., Torchio, F., Boccacci, P., Gambino, G., Gerbi, V., Rolle, L., 2017. Ozone improves the aromatic fingerprint of white grapes. Sci. Rep. 7, 16301.

Simkin, S.M., Allen, E.B., Bowman, W.D., et al., 2016. Conditional vulnerability of plant diversity to atmospheric nitrogen deposition across the United States. PNAS 113, 4086-4091.

Simpson, D., Arneth, A., Mills, G., Solberg, S., Uddling, J., 2014. Ozone - the persistent menace: interactions with the N cycle and climate change. Curr. Opin. Environ. Sust. 9-10, 9-19.

Sinclair, B.J., Gibbs, A.G., Roberts, S.P., 2007. Gene transcription during exposure to, and recovery from, cold and desiccation stress in Drosophila melanogaster. Insect Mol. Biol. 16, 435-443.

Southam, C.M., Ehrlich, J., 1943. Effects of extracts of western red-cedar heartwood on certain wood-decaying fungi in culture. Phytopathology 33, 517-524.

Stebbing, A.R.D., 1982. Hormesis-The stimulation of growth by low levels of inhibitors. Sci. Total Environ. 22, 213-234.

Sugai, T., Kam, D.-G., Agathokleous, E., Watanabe, M., Kita, K., Koike, T., 2018. Growth and photosynthetic response of two larches exposed to $\mathrm{O}_{3}$ mixing ratios ranging from preindustrial to near future. Photosynthetica 56. https://doi.org/10.1007/s11099-017-0747-7

Tani, A., Ohno, T., Saito, T., Sohei, I., Yonekura, T., Miwa, M., 2017. Effects of ozone on isoprene emission from two major Querqus species native to East Asia. J. Agr. Meteorol. 73, 195-202.

Tzortzakis, N., Singleton, I., Barnes, J., 2007. Deployment of low-level ozone-enrichment for the preservation of chilled fresh produce. Postharv. Biol. Technol. 43, 261-270.

Tzortzakis, N., Taybi, T., Roberts, R., Singleton, I., Borland, A., Barnes, J., 2011. Low-level atmospheric ozone exposure induces protection against Botrytis cinerea with down-regulation of ethylene-, jasmonate- and pathogenesis-related genes in tomato fruit. Postharv. Biol. Technol. 61, 152-159.

U.S. EPA (Environmental Protection Agency), 2014. Welfare risk and exposure assessment for ozone - final report. U.S. Environmental Protection Agency, Office of Air Quality Planning and Standards, North Carolina. pp. 472.

Vázquez-Ybarra, J.A., Peña-Valdivia, C.B., Trejo, C., Villegas-Bastida, A., BenedictoValdéz, S., Sánchez-García, P., 2015. Promoting growth of lettuce plants (Lactuca sativa L.) with sublethal ozone doses applied to culture medium. Rev. Fitotec. Mex. Vol. 38, 405-413. 
Yalpani, N., Enyedi, A.J., León, J., Raskin, I., 1994. Ultraviolet light and ozone stimulate accumulation of salicylic acid, pathogenesis-related proteins and virus resistance in tobacco. Planta 193, 372-376.

Yamaguchi, M., Watanabe, M., Matsumura, H., Kohno, Y., Izuta, T., 2011. Experimental studies on the effects of ozone on growth and photosynthetic activity of Japanese forest tree species. Asian J. Atmos. Environ. 5-2, 65-78.

Yamaguchi, M., Watanabe, M., Tabe, C., Naba, J., Matsumura, H., Kohno, Y., Izuta, T., 2012. Effects of sulfur dioxide on growth and net photosynthesis of six Japanese forest tree species grown under different nitrogen loads. Trees 26, 1859-1874.

Ye, L., Fu, X., Ge, F., 2011. Enhanced sensitivity to higher ozone in a pathogen-resistant tobacco cultivar. J. Exp. Bot. 63, 1341-1347.

Yuan, X., Calatayud, V., Gao, F., Fares, S., Paoletti, E., Tian, Y., Feng, Z., 2016. Interaction of drought and ozone exposure on isoprene emission from extensively cultivated poplar. Plant Cell Environ. 39, 2276-2287.

Wang, W., Wan, S.-B., Zhang, P., Wang, H.-L., Zhan, J.-C., Huang, W.D., 2008. Prokaryotic expression, polyclonal antibody preparation of the stilbene synthase gene from grape berry and its different expression in fruit development and under heat acclimation. Plant Physiol. Biochem. 46, 1085-1092.

Wang, X.N., Agathokleous, E., Qu, L., Watanabe, M., Koike, T., 2016. Effects of $\mathrm{CO}_{2}$ and/or $\mathrm{O}_{3}$ on the interaction between root of woody plants and ectomycorrhizae. J. Agr. Meteorol. 72, 95-105.

Wang, X., Agathokleous, E., Qu, L., Fujita, S., Watanabe, M., Tamai, Y., Mao, Q., Koyama, A., Koike, T., 2018. Effects of simulated nitrogen deposition on ectomycorrhizae community structure in hybrid larch and its parents grown in volcanic ash soil: the role of phosphorous. Sci. Total Environ. https://doi.org/10.1016/j.scitotenv.2017.08.283

Watanabe, M., Matsuo, N., Yamaguchi, M., Matsumura, H., Kohno, Y., Izuta, T., 2010. Risk assessment of ozone impact on the carbon absorption of Japanese representative conifers. Eur. J. Forest Res. 129, 421-430.

Watanabe, M., Yamaguchi, M., Matsumura, H., Kohno, Y., Izuta, T., 2012. Risk assessment of ozone impact on Fagus crenata in Japan: consideration of atmospheric nitrogen deposition. Eur. J. Forest Res. 131, 475-484.

Watanabe, T., Urayama, M., Shinano, T., Okada, R., Osaki, M., 2015. Application of ionomics to plant and soil in fields under long- term fertilizer trials. SpringerPlus 4, 781. 
Weigel, H.J., Adaros, G., Jäger, H.J., 1990. Yield responses of different crop species to long-

942 term fumigation with sulphur dioxide in open-top chambers. Environ. Pollut. 67, 15-28.

943 Williamson, J.L., Mills, G., Hayes, F., Jones, T., Freeman, C., 2016. How do increasing 944 background concentrations of tropospheric ozone affect peatland plant growth and carbon gas 945 exchange? Atmos. Environ. 127, 133-138.

946

947

948

949

950

951

952

953

954

955

956

957

958

959

960

961

962

963

964

965

966

967

968

969

970

971

972 
973 Table 1

974 Table 1 Quantitative properties of exposure-response relationships which displayed hormesis.

975 Hormesis was observed in 52 relationships of which 38 displayed both LOAEL and NOAEL.

976 Max indicates maximum stimulatory response and NOAEL:max the factor at which the

977 maximum stimulatory response occurred below the NOAEL. With regards to magnitude range,

978 the number of curves falling within the corresponding magnitude range is given along with the

979 percentage of 52 hormetic curves in parenthesis.

980 Note: In one dose-response relationship, the maximum stimulation was lower than 105\% (102\%)

981 however statistically significant and thus was considered as $105 \%$ in the calculations of the 982 magnitude range.

\begin{tabular}{|ll|}
\hline \multicolumn{2}{|l|}{ Maximum stimulation (52 relationships) } \\
\hline Arithmetic mean max & $130.6 \%$ \\
Geometric mean max & $129.1 \%$ \\
Minimum max & $102.0 \%$ \\
Maximum max & $212.0 \%$ \\
Magnitude range (52 relationships) & \\
105\% < max $\leq 125 \%$ & $25(48.1 \%)$ \\
$126 \% \leq \max \leq 150 \%$ & $23(44.2 \%)$ \\
$151 \% \leq \max \leq 200 \%$ & $4(7.7 \%)$ \\
$105 \%<\max \leq 124 \%$ & $22(42.3 \%)$ \\
$110 \%<\max <150 \%$ & $41(78.8 \%)$ \\
125\% $\leq$ max $\leq 161 \%$ & $28(53.8 \%)$ \\
NOAEL:max (52 relationships) & \\
Arithmetic mean NOAEL:max & 1.56 \\
Geometric mean NOAEL:max & 1.44 \\
Minimum NOAEL:max & 1.00 \\
Maximum NOAEL:max & 4.00 \\
LOAEL:NOAEL (41 relationships) & \\
Arithmetic mean LOAEL:NOAEL & 1.86 \\
Geometric mean LOAEL:NOAEL & 1.77 \\
Minimum LOAEL:NOAEL & 1.08 \\
Maximum LOAEL:NOAEL & 4.39 \\
\hline
\end{tabular}

983

984

985

986

987

988

989

990

991

992

993

994

995 
997 Fig 1. The concept of hormesis. The figure is created based on data reported by Agathokleous et 998 al. (2016b), where the rate of non-photochemical quenching of chlorophyll $a$ fluorescence $(N P Q)$ was measured in Lemna minor L. (duckweed) at 24 (early response), 72 (intermediate response) and 120 (late response) $\mathrm{h}$ from the initiation of exposure to $0,148,593,1185$ or $2370 \mathrm{mg} \mathrm{l}^{-1}$ ethylenediurea in the growing solution media. $N P Q$ indicates the heat dissipation of excitation Energy (Moustakas et al., 2017).

1003 Note: The change in biological endpoints in response to treatment (exposure level) relative to the 1004 control group (\% control) was calculated as Response $=\mu_{C} / \mu_{T} \times 100$, where $\mu_{c}$ is the mean value of $\mu$ of the control group and $\mu_{T}$ is the mean value of $\mu$ of each exposure level, such that reference point is $100 \%$. The curves are modeled based on the calculated response data and logtransformed EDU concentrations on abscissa.

1008 Fig 2. Representative examples of $U$-shaped dose-response curves induced by different types of environmental factors. Curves are plotted across observed data (solid curves) and modeled ones (dashed curves), using several endpoints: a) number of pods; b) total plant leaf area; c) net photosynthetic rate at $1700 \mu \mathrm{mol} \mathrm{CO} \mathrm{mol}^{-1}\left(A_{\max }\right)$; d) diffusive conductance; e) shoot dry matter and malondialdehyde (MDA) content; f) relative growth rate (RGR) and net assimilation rate

$1013\left(A_{\text {net }}\right)$; g) yield and shoot dry matter; h) total plant leaf area, number of pods per plant, seed 1014 weight and yield; i) straw and ears dry weight; and j) grain yield and total dry weight. The 1015 endpoints were measured in different biological models: (a) Pot-grown seedlings of an $\mathrm{O}_{3^{-}}$ 1016 sensitive (S156) and an $\mathrm{O}_{3}$-tolerant (R123) genotype of snap bean (Phaseolus vulgaris L.) 1017 chronically exposed to increasing levels of ambient air temperature in outdoor plant environment 1018 chambers (OPECs) (Agathokleous et al., 2017a); (b) Pot-grown seedlings of Quercus serrata 1019 Murray 1784 (deciduous), Fagus crenata Blume (deciduous) and Castanopsis sieboldii (Makino) 1020 Hatus (evergreen) chronically (two growing seasons) exposed to increasing levels of $\mathrm{SO}_{2}$ gas in 1021 open top chambers (OTCs) and theoretically $0 \mathrm{~kg} \mathrm{ha}^{-1}$ year $^{-1}$ soil nitrogen deposition (Yamaguchi 1022 et al., 2012); (c) Pot-grown seedlings of F. crenata chronically (two growing seasons) exposed to 1023 increasing levels of simulated nitrogen deposition with soil $\mathrm{HNO}_{3}$ (Izuta et al., 2004); (d) Pot1024 free-grown snap beans seedlings ( $P$. vulgaris L. cv 'GV50') exposed to increasing levels of $\mathrm{H}_{2} \mathrm{~S}$ gas for $18 \pm 2 \mathrm{~d}$ (66 hours in total) in rectangular minimum interference chambers when $\mathrm{O}_{3}$ in atmosphere was either 0 (theoretically) or $72 \mathrm{nmol} \mathrm{mol}^{-1}$ (Coyne and Bingham, 1978); (e) Potgrown seedlings of spring barley (Hordeum vulgare L.) exposed to increasing levels of UV-B rays in phytotron chambers for one week (Kacienè et al., 2015); (f) Pot-grown seedlings of 
sunflower (Helianthus annuus L. cv Russian Mammoth) exposed to increasing levels of $\mathrm{NO}_{2}$ in 1030 artificially lit growth cabinets for two weeks (Okano et al., 1985); (g) Pot-grown seedlings of 1031 barley (H. vulgare cv Hockey) and rape (Brassica napus L. cv Callypso) exposed to increasing 1032 levels of $\mathrm{SO}_{2}$ gas in OTCs for about three months (Weigel et al., 1990); (h) Pot-free-grown 1033 seedlings of bean (P. vulgaris L. cv Nerina) exposed to increasing levels of $\mathrm{O}_{3}$ in OTCs for about 1034 three months (Sanders et al., 1992); and (i-j) Pot-free-grown plants of winter barley (H. vulgare 1035 L. cv. Sonja) exposed to increasing levels of $\mathrm{SO}_{2}$ in an open-air exposure system from November 1036 to July (McLeod et al., 1988).

1037 Note 1: The control UV-B exposure level in Kacienè et al. (2015) is not given, and, thus, it is considered $0.25 \mathrm{~kJ} \mathrm{~m}^{-2} \mathrm{~d}^{-1}$ because the exposure levels in the experiment were increasing on a 1039 two-fold power. The response of each treatment in McLeod et al. (1988) is based its own 1040 corresponding control plots, thus the lowest exposure level is around $105 \%$.

1041 Note 2: When possible, data of each group (exposure level) were averaged per experimental unit 1042 and the averages were further averaged to give one estimate for each exposure level. The change 1043 in biological endpoints in response to treatment (exposure level) relative to the control group (\% 1044 control) was calculated as Response $=\mu_{C} / \mu_{T} \times 100$, where $\mu_{c}$ is the mean value of $\mu$ of the 1045 control group and $\mu_{T}$ is the mean value of $\mu$ of each exposure level, such that reference point is $1046100 \%$. Extraction of data from reviewed articles, when it was needed, was done using image 1047 analysis software (Adobe Photoshop CS4 Extended v.11, Adobe Systems Incorporated, CA, 1048 USA).

1049 Fig 3. Representative examples of U-shaped exposure-response curves induced by $\mathrm{O}_{3}$ stress. 1050 Curves are plotted across observed data (solid curves) and modeled ones (dashed curves), using 1051 different endpoints: a) stem height and water use efficiency (WUE); b) mesophyll conductance $1052\left(g_{m}\right)$; c) methane fluxes; d) carotenoids content; e) height growth; and f) leaf area per pod and 1053 kernel yield. The endpoints were measured in different biological models: (a) Pot-grown 1054 seedlings of Metasequoia glyptostroboides exposed to 7.5, 50, 100 and $200 \mathrm{nmol} \mathrm{O}_{3} \mathrm{~mol}^{-1}$ in 1055 open top chambers (OTCs) for 25 days and 8 hours per day (09:00-17:00) (Feng et al., 2008b);

1056 (b) Pot-grown seedlings of an $\mathrm{O}_{3}$-sensitive (S156) and two $\mathrm{O}_{3}$-tolerant (R123, R331) genotypes 1057 of snap bean (Phaseolus vulgaris L.) exposed to 0.93, 14.79, 30.05 and $59.33 \mathrm{nmol} \mathrm{O}_{3} \mathrm{~mol}^{-1}$ (12$1058 \mathrm{~h}$ average, 08:00-20:00) in outdoor plant environment chambers (OPECs); the experiment was 1059 conducted from 21 November 2003 to 12 February 2004 and from 20 February 2004 to 13 May 10602004 (Flowers et al., 2007); (c) Peatland mesocosms from an upland peat bog in UK were 1061 exposed to eight $\mathrm{O}_{3}$ levels in solardomes from May to August (24 h AOT0) (Williamson et al., 
1062 2016); d) Pot-grown seedlings of spring barley (Hordeum vulgare L.) exposed to 11.25, 22.5, 45,

106390 and $180 \mathrm{nmol} \mathrm{O}_{3} \mathrm{~mol}^{-1}$ in phytotron chambers for one week and 12 hours per day (Kacienè et 1064 al., 2015); e) Pot-grown seedlings of sugar maple (Acer saccharum Marsh.) and yellow poplar 1065 (Liriodendron tulipifera L.) exposed to 0, 50, 100 and $150 \mathrm{nmol} \mathrm{O}_{3} \mathrm{~mol}^{-1}$ in indoor exposure 1066 chambers for 28 days and six hours per day (Kress and Skelly 1982); and f) Pot-grown plants of 1067 winter wheat (Triticum aestivum L., genotype MD01W-28-08-11) exposed to 10, 50, 75 and 100 $1068 \mathrm{nmol} \mathrm{O} \mathrm{mol}^{-1}$ in OTCs from heading to harvest (Mashaheet, 2016), and pot-free-grown 1069 seedlings of bean (P. vulgaris L. cv Nerina) exposed to 10, 20, 26, 32, 38, 45 and $50 \mathrm{nmol} \mathrm{O}_{3}$ $1070 \mathrm{~mol}^{-1}$ in OTCs for about three months (Sanders et al., 1992). More information regarding 1071 calculations can be found in Note 1 of Fig 2.

1072 Notes: The lowest exposure level in Feng et al. (2007) was reported as $<15 \mathrm{nmol} \mathrm{mol}^{-1}$ and thus 1073 it was considered $7.5 \mathrm{nmol} \mathrm{mol}^{-1}$ as the average between 0 and $15 \mathrm{nmol} \mathrm{mol}^{-1}$. The control $\mathrm{O}_{3}$ 1074 exposure level in Kacienè et al. (2015) is not given, and, thus, it is considered $11.25 \mathrm{nmol} \mathrm{mol}^{-1}$ 1075 because a) the maximum $\mathrm{O}_{3}$ mixing ratio in charcoal-filtered chambers is around this level and 1076 b) the other $\mathrm{O}_{3}$ exposure levels in the experiment were increasing on a two-fold power. The 1077 control $\mathrm{O}_{3}$ exposure level in Mashaheet (2016) is not clearly given, and, thus, it is considered 10 $1078 \mathrm{nmol} \mathrm{mol}^{-1}$ because the maximum $\mathrm{O}_{3}$ mixing ratio in charcoal-filtered chambers is commonly 1079 around this level. The leaf area per pod in Sanders et al. (1992) was calculated as the average 1080 dose responses of two harvests conducted at different time points.

1081 Fig 4. Ozone-induced hormesis in two competitive larches. Observations come from pot-free1082 grown seedlings of the decidua conifers Japanese larch (Larix kaempferi (Lamb.) Carr.) and its 1083 hybrid larch $\mathrm{F}_{1}$ (Larix gmelinii var. japonica (Maxim. ex Regel) Pilg. $\times$ L. kaempferi) exposed to 1084 increasing levels of $\mathrm{O}_{3}$ in open top chambers (OTCs) for two growing seasons, during day-light 1085 hours (Sugai et al. 2018). The lowest $\mathrm{O}_{3}$ level is comparable to pre-industrial $\mathrm{O}_{3}$ levels. Net 1086 photosynthetic rate at saturated $\mathrm{CO}_{2}\left(A_{\text {max }}\right)$, transpiration rate at ambient $\mathrm{CO}_{2}\left(E_{380}\right)$, maximum 1087 rate of Ribulose-1,5-bisphosphate carboxylase/oxygenase (RuBisCO) carboxylation $\left(V c_{\max }\right)$, 1088 maximum rate of photosynthetic electron transport $\left(J_{\max }\right)$, total chlorophyll content per needle 1089 area and total plant dry matter (above and below ground) are shown. More information regarding 1090 calculations can be found in Note 1 of Fig 2.

1091 Fig 5. Species-specific hormesis in three evergreen and seven deciduous species depicted by root, 1092 shoot and total plant dry matter as biological endpoints. The exposure-response curves are 1093 plotted across observed data (solid curves) and modeled ones (dashed curves) of pot-grown 1094 seedlings of ten tree species exposed to $0,50,100$ and $150 \mathrm{nmol} \mathrm{O}_{3} \mathrm{~mol}^{-1}$ in indoor exposure 1095 chambers for 28 consecutive days and six hours per day (Kress and Skelly, 1982). The evergreen 
1096 species were: a) loblolly pine full-sib collection (Pinus taeda L.); b) pitch pine (P. rigida Mill.); 1097 c) Virginia pine (P. virginiana Mill.). The deciduous species were: d) sweetgum (Liquidambar 1098 styraciflua L.); e) American sycamore (Platanus occidentalis L.); f) sugar maple (Acer 1099 saccharum Marsh.); g) yellow poplar (Liriodendron tulipifera L.); h) white ash (Fraxinus 1100 americana L.); i) green ash (F. pennsylvanica Marsh); and j) willow oak (Quercus phellos L.). 1101 More information regarding calculations can be found in Note 1 of Fig 2.

1102

1103

1104

1105

1106

1107

1108 
Fig 1

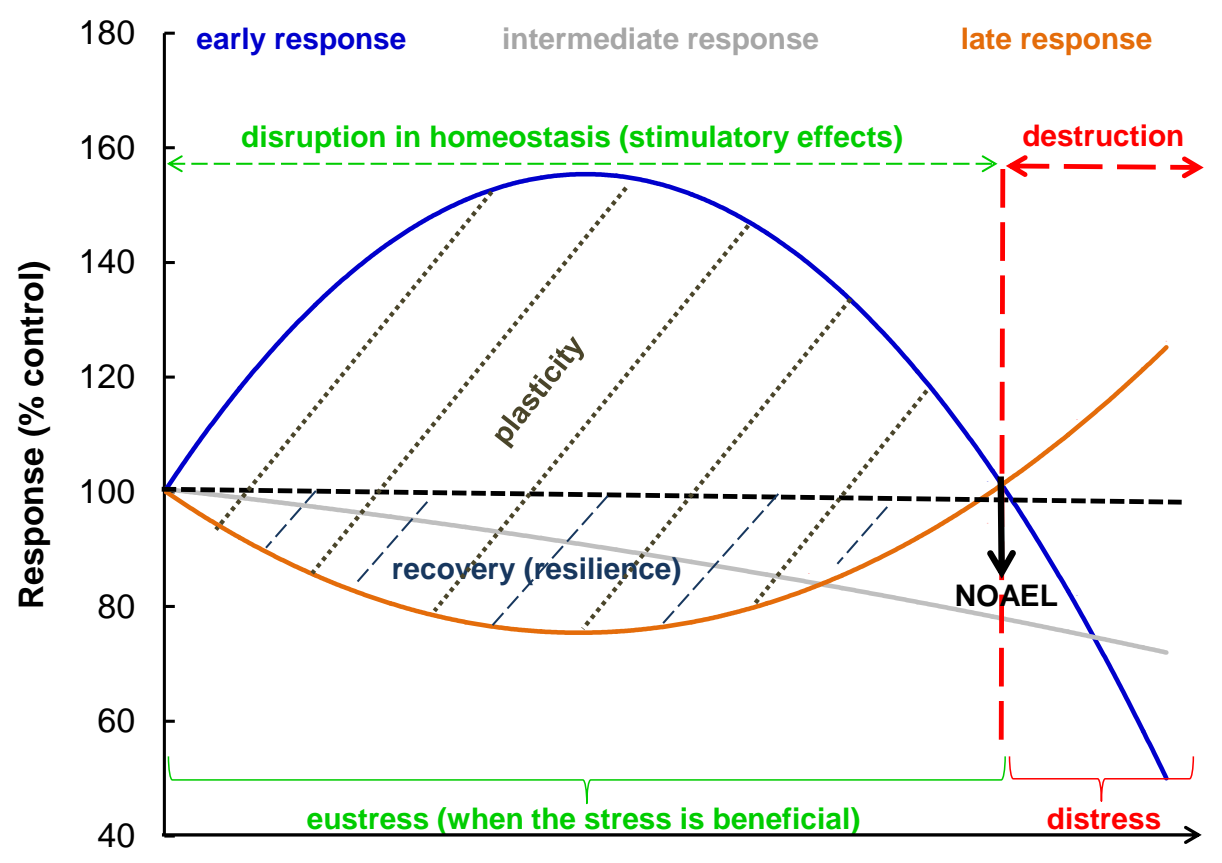

Levels of exposure 
Fig 2
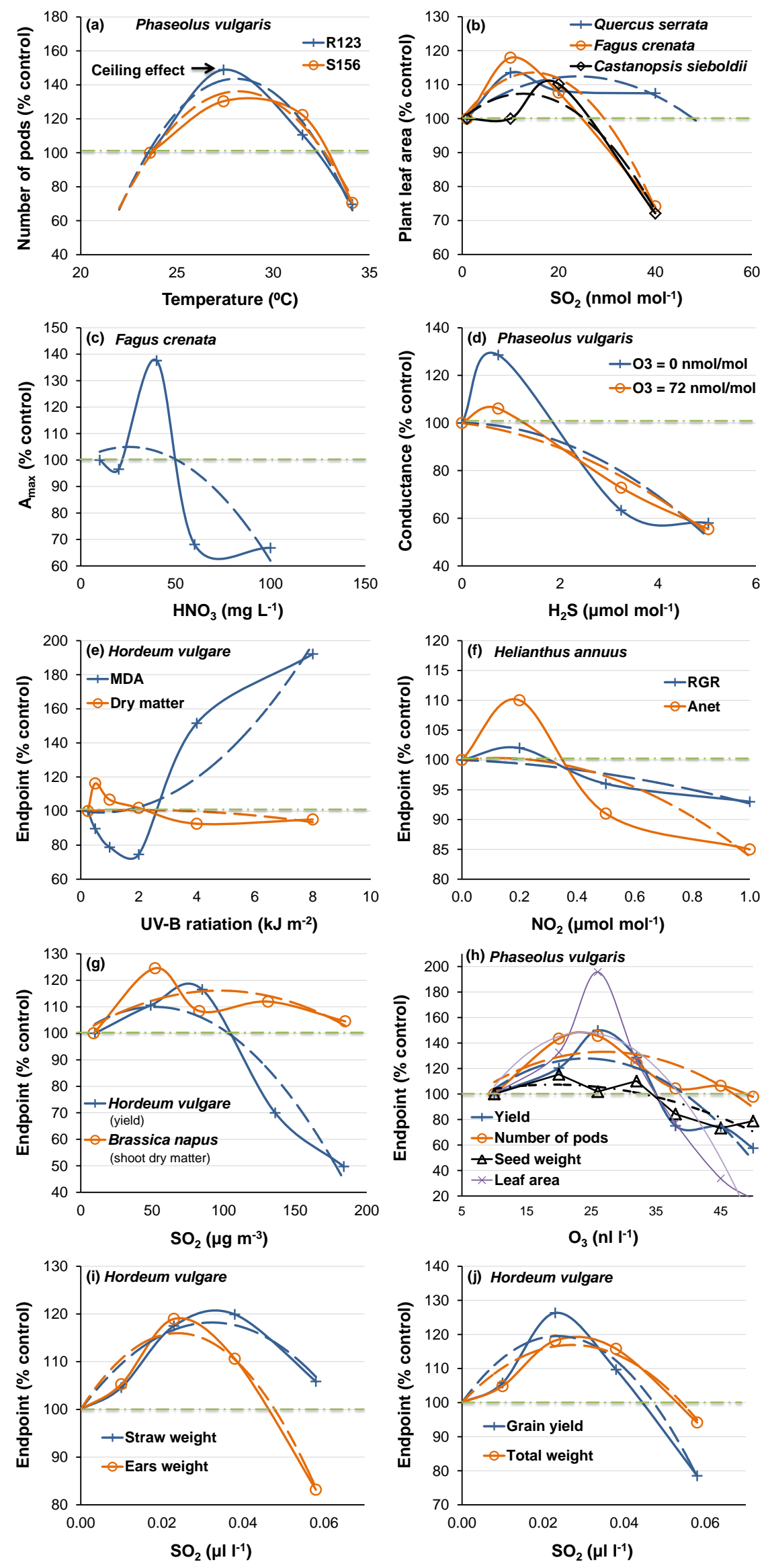
Fig 3
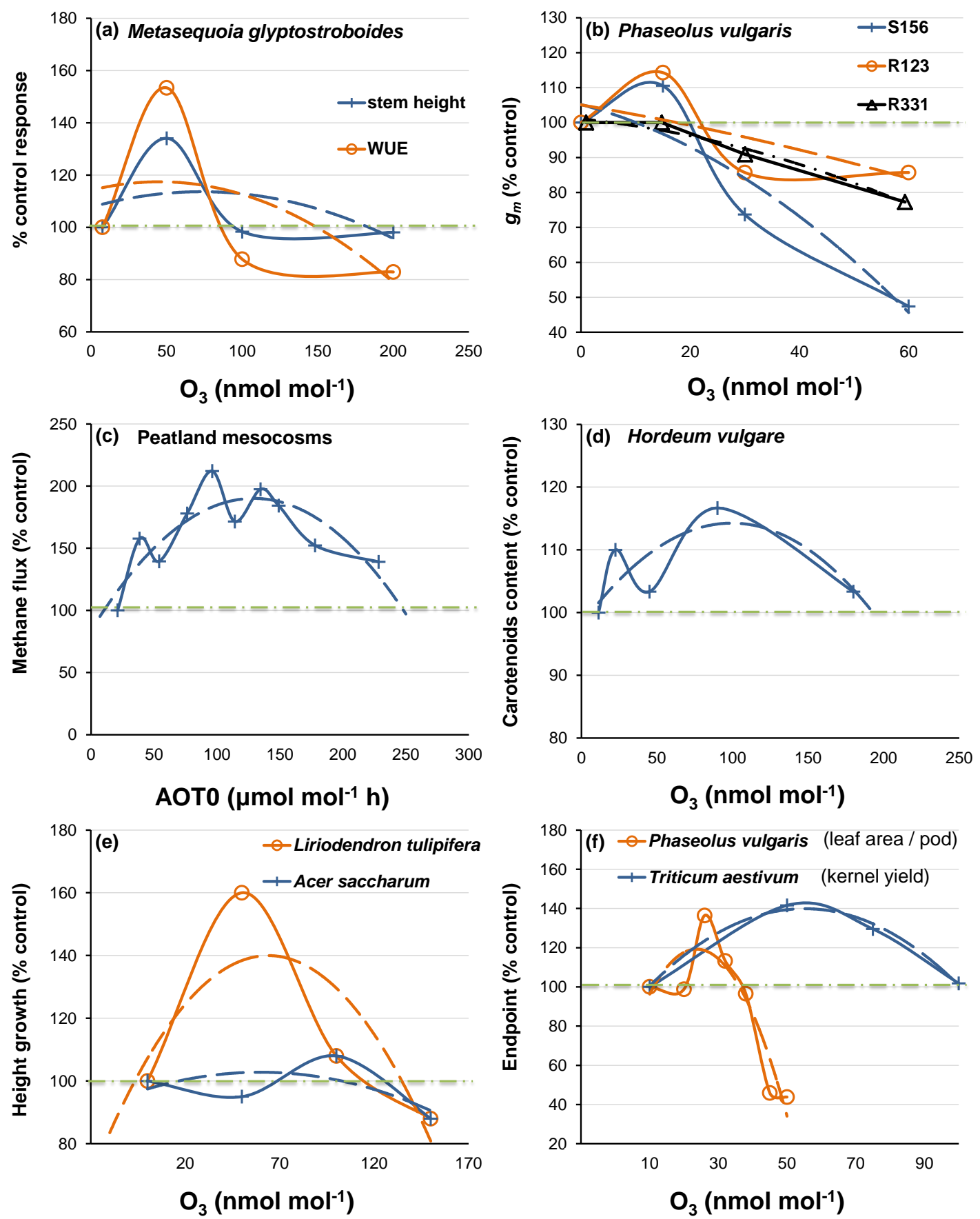
Fig 4
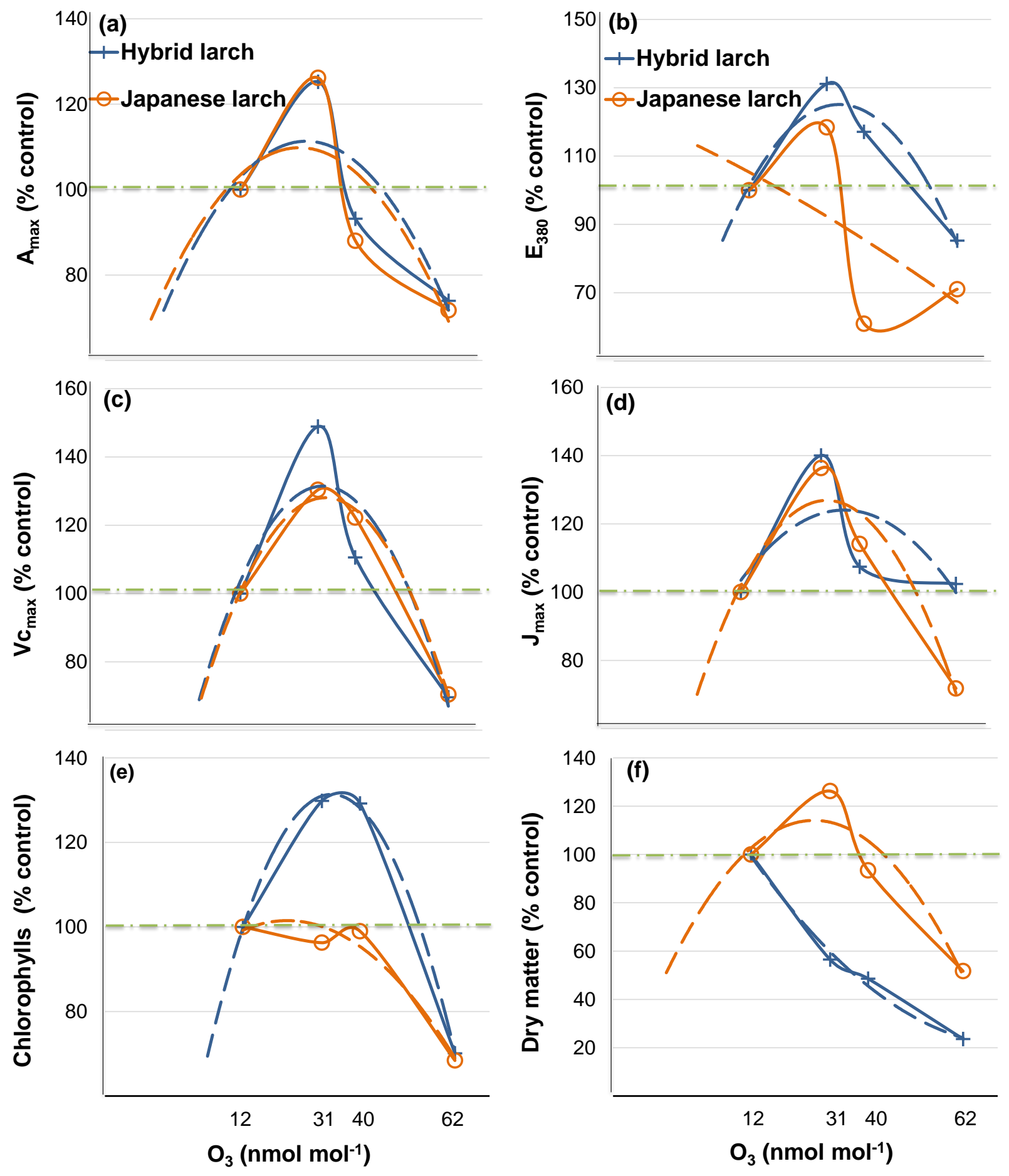
Fig 5
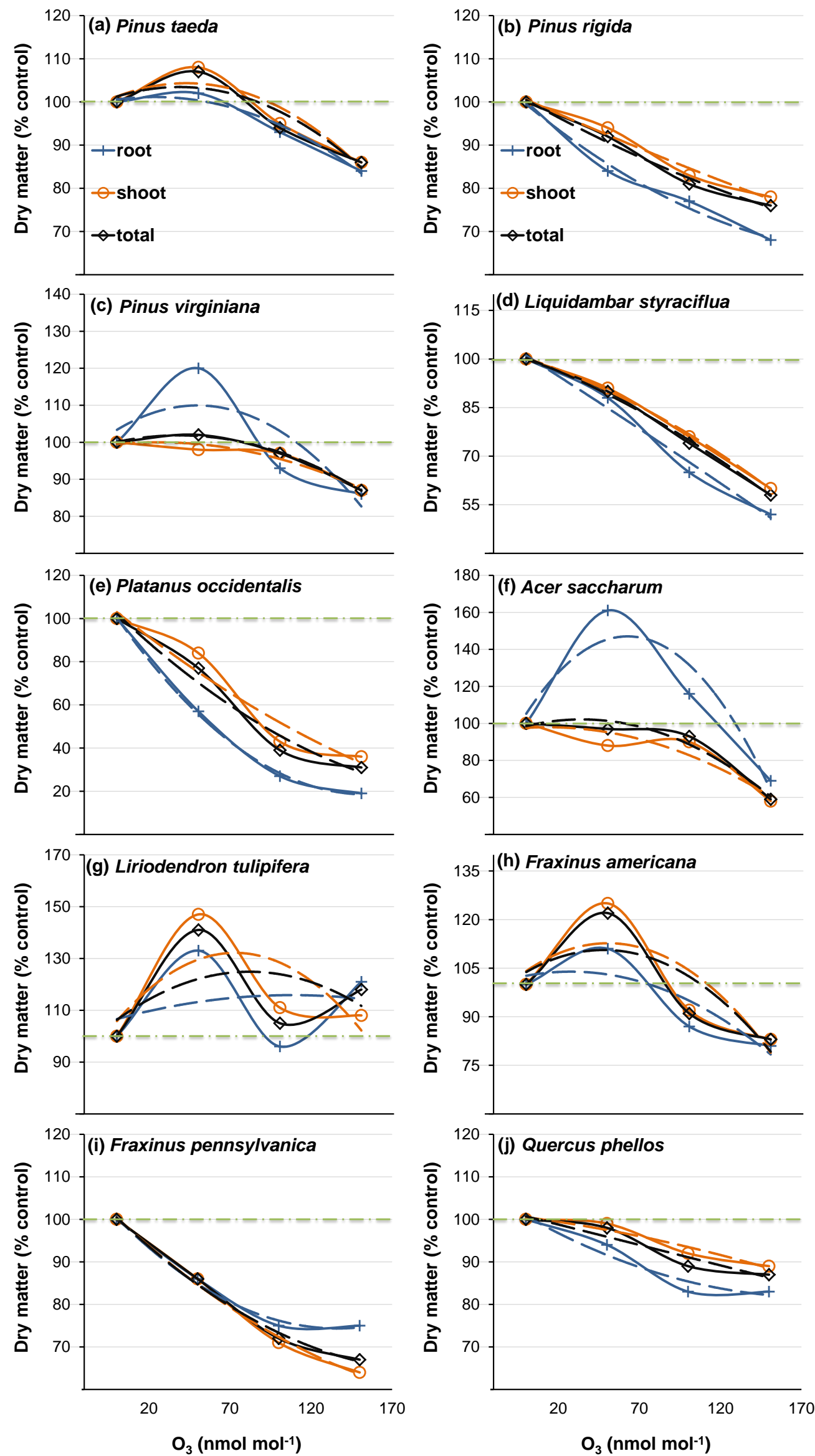